\title{
Studies on Human Antigens of Aspergillus versicolor
}

\author{
by \\ WeIDONg ZhaO \\ M.Sc. (Shandong University, Jinan, China)
}

A thesis submitted to the Faculty of Graduate Studies and Research in partial fulfillment of the requirements for the degree of

Master of Science

Department of Chemistry

Carleton University

Ottawa, Ontario

August, 2006

(C) copyright 2006

Weidong Zhao 


$\begin{array}{ll}\begin{array}{l}\text { Library and } \\ \text { Archives Canada }\end{array} & \begin{array}{l}\text { Bibliothèque et } \\ \text { Archives Canada }\end{array} \\ \begin{array}{l}\text { Published Heritage } \\ \text { Branch }\end{array} & \begin{array}{l}\text { Direction du } \\ \text { Patrimoine de l'édition }\end{array} \\ \begin{array}{l}\text { 395 Wellington Street } \\ \text { Ottawa ON K1A ON4 }\end{array} & \begin{array}{l}\text { 395, rue Wellington } \\ \text { Ottawa ON K1A ON4 } \\ \text { Canada }\end{array}\end{array}$

Your file Votre référence ISBN: 978-0-494-18380-9 Our file Notre référence ISBN: 978-0-494-18380-9

NOTICE:

The author has granted a nonexclusive license allowing Library and Archives Canada to reproduce, publish, archive, preserve, conserve, communicate to the public by telecommunication or on the Internet, loan, distribute and sell theses worldwide, for commercial or noncommercial purposes, in microform, paper, electronic and/or any other formats.

The author retains copyright ownership and moral rights in this thesis. Neither the thesis nor substantial extracts from it may be printed or otherwise reproduced without the author's permission.
AVIS:

L'auteur a accordé une licence non exclusive permettant à la Bibliothèque et Archives Canada de reproduire, publier, archiver, sauvegarder, conserver, transmettre au public par télécommunication ou par l'Internet, prêter, distribuer et vendre des thèses partout dans le monde, à des fins commerciales ou autres, sur support microforme, papier, électronique et/ou autres formats.

L'auteur conserve la propriété du droit d'auteur et des droits moraux qui protège cette thèse. $\mathrm{Ni}$ la thèse ni des extraits substantiels de celle-ci ne doivent être imprimés ou autrement reproduits sans son autorisation.
In compliance with the Canadian

Privacy Act some supporting forms may have been removed from this thesis.

While these forms may be included in the document page count, their removal does not represent any loss of content from the thesis.
Conformément à la loi canadienne sur la protection de la vie privée, quelques formulaires secondaires ont été enlevés de cette thèse.

Bien que ces formulaires aient inclus dans la pagination, il n'y aura aucun contenu manquant.

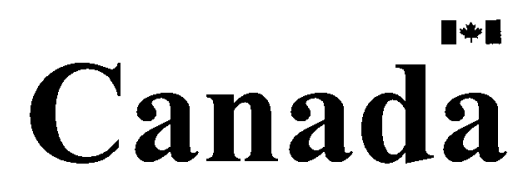




\begin{abstract}
Aspergillus versicolor, an important indoor mold, is associated with a characteristic moisture failures condensation on wallboard. Human sera from atopic patients have been used to mine antigens from spore and mycelium to produce polyclonal antibodies to spore surface proteins, permitting the isolation, characterization and the production of monoclonal antibodies to these proteins.
\end{abstract}

The Aspergillus versicolor antigenic proteins were found in both mycelia and the $A$. versicolor culture media. The proteins were separated from both the $A$. versicolor mycelium (AVL) and the $A$. versicolor culture supernatant (AVS). The protein was further fractionated by ammonium sulfate precipitation. The antigenic protein band was identified by Western blotting analysis using human sera as a source of primary antibody.

The A.versicolor proteins were partially purified by ion exchange chromatography. The antigenic proteins were identified by performing Coomass Blue Stain and Western blotting. After the proteins were identified, the molecular weights were determined by SDS-PAGE, which were $47 \mathrm{kDa}$ for AVS, $65 \mathrm{kDa}$ and $61 \mathrm{kDa}$ for AVL. The AVL and AVS protein bands on SDS-PAGE were collected, and were used to raise polyclonal antibodies. The polyclonal antibody was purified using protein G column. The AVS polyclonal antibody was further purified by CNBr-Sepharose column. After the purification, the polyclonal antibodies were used as primary antibody instead of human sera. The AVS protein was further purified by gel filtration chromatography. The molecular weight of AVS was calculated by gel filtration to be $45 \mathrm{kDa}$ by gel filtration. 
An ELISA was used to determine the immunological activity of allergenic protein. The crossing reactivity of polyclonal antibodies against other fungal spore and mycelia extract was determined. The results show that the AVS polyclonal antibody is specific to $A$. versicolor. Thus purified AVS protein was collected and was used to raise monoclonal antibody. 


\section{ACKNOWLEDGEMENTS}

The realization of this thesis is firstly attributed to help from my supervisor, Dr. Miller. From the first day I began my research work at the lab, he was always helpful, and encouraged me through every failure and success. I was impressed by his dedication and enthusiasm to research work, and felt fortunate to have him as my supervisor.

My thanks go to Dr. Jianping Xu, who taught me about the biochemistry techniques, and shared with me about his experiences.

I also would like to thank all the past and present members of the research laboratory, for their help and cooperation.

I am grateful to my husband Xin and my daughter Didi for their unconditional love and support. 


\section{LIST OF ACRONYMS}

AP

APS

BCIP

BSA

CBB

EDTA

ELISA

IgG

kDa

NBT

OD

PAb

PBS

PBST

SDS-PAGE

TBST

TEMED ammonium phosphate

alkaline phosphatase

5-Bromo-4-chloro-3-indolyl phosphate dipotassium bovine serum albumin Coomassie Brilliant Blue EthyleneDiamineTetra-acetic Acid Enzyme-Linked Immunosorbent Assay Immunoglobulin G kiloDalton nitrotetrazoline blue chloride optical density polyclonal antibody Phosphate Buffered Saline phosphate buffered saline tween-20 sodium dodecyl sulfate polyacrylamide gel electrophoresis

Tris-buffered saline tween-20 $\mathrm{N}, \mathrm{N}, \mathrm{N}^{\prime}, \mathrm{N}^{\prime}$-tetramethylethylenediamine 


\section{TABLE OF CONTENTS}

Acceptance Sheet

Abstract

Acknowledgements v v

List of Acronyms vi

List of Tables $\quad x$

List of Figures $\quad$ xi

1. INTRODUCTION 1

1.1. Fungi 1

1.2. Indoor Fungi 1

1.2.1. Indoor sources 1

1.3. Population Health Issues 3

1.3.1. Mold increase respiratory disease 3

$\begin{array}{ll}\text { 1.3.2. Mold increased allergic disease } & 7\end{array}$

$\begin{array}{lll}\text { 1.3.2.1. Mold Allergy } & 7\end{array}$

$\begin{array}{lll}\text { 1.3.2.1.1. Allergy to airborne molds } & 7\end{array}$

1.3.2.2. Allergenic species of fungi and their allergens $\quad 8$

1.3.2.3. Allergic clinical syndromes 9

1.3.2.3.1. Allergic rhinitis 9

$\begin{array}{ll}\text { 1.3.2.3.2. Allergic bronchopulmonary aspergillosis } & 10\end{array}$

$\begin{array}{ll}\text { 1.3.2.3.3. Allergic fungal sinusitis } & 10\end{array}$

1.3.3. The theory of the allergic respiratory response to fungi 10 
$\begin{array}{ll}\text { 1.3.3.2. Humoral components } & 11\end{array}$

$\begin{array}{ll}\text { 1.3.3.2.1. Antibodies } & 12\end{array}$

$\begin{array}{ll}\text { 1.3.3.2.2. Complement System } & 12\end{array}$

1.3.3.2.3. Mediators of Allergic Response 13

1.4. Aspergillus 13

$\begin{array}{ll}\text { 1.4.1. Biodeterioration } & 14\end{array}$

$\begin{array}{ll}\text { 1.4.2. Mycotoxins } & 14\end{array}$

$\begin{array}{ll}\text { 1.4.3. Allergic reactions } & 15\end{array}$

1.5. Aspergillus versicolor 15

$\begin{array}{ll}\text { 1.6. Purification of fungal allergens } & 16\end{array}$

$\begin{array}{ll}\text { 1.6.1. Monoclonal antibodies } & 17\end{array}$

$\begin{array}{ll}\text { 1.6.2. Test methods for purified extracts } & 18\end{array}$

$\begin{array}{ll}\text { 1.6.3. Standardization of extracts } & 18\end{array}$

2. MATERIALS AND METHODS 21

$\begin{array}{ll}\text { 2.1. Cultures } & 21\end{array}$

2.2. Antibodies 22

2.3. Affinity purification of anti-A.versicolor goat polycolonal antibodies 23

2.4. Protein assays 24

$\begin{array}{ll}\text { 2.5. Protein extraction } & 25\end{array}$

$\begin{array}{ll}\text { 2.5.1. Extracellular proteins } & 25\end{array}$

2.5.2. Intracellular proteins 25

2.6. Ion exchange chromatography 26 
2.7. Gel filtration chromatography

2.8. SDS-Polyacrylamide gel electrophoresis 38

2.9. Immunoblotting 29

2.10. Immune affinity purification $\quad 30$

2.11. Molecular weight determinations 31

2.12. Cross-reactivity experiments using AVL-PAB and AVS-PAB 32

2.13. Purified AVS 33

2.14. Spore extracts 33

2.15. Mycelial extracts $\quad 37$

2.16. Identification of antigenic protein using CBB stained gels and immunoblots 38

3. Results $\quad \mathbf{4 0}$

$\begin{array}{ll}\text { 3.1. Polyclonal antibody } & 40\end{array}$

3.2. Protein isolation 40

3.2.1. Separation of antigenic proteins from A. versicolor $\quad 40$

3.2.2. Identification of antigenic proteins 46

3.3. Further purification of AVS

3.4. Molecular weight of AVS $\quad 62$

3.5. Cross-reactivity experiments using AVL-PAb and AVS-PAb 62

$\begin{array}{ll}\text { 3.6. } & \text { Purified AVS } \\ \end{array}$

$\begin{array}{ll}\text { 3.7. Spore extracts } & 67\end{array}$

3.8. Mycelial extracts 67 


\section{List of Tables}

Table 1. Spores mean protein concentration in cross activity ELISA

Table 2. Recovery of the AVS protein through purification steps

Table 3. The cross reactivity of AVL PAb with spores of different species on ELISA assay

Table 4. The cross reactivity of AVS PAb with spores of different species on ELISA assay

Table 5. The cross reactivity of AVS PAb with different AVS spore strains on ELISA assay

Table 6. Total a mount of isolated pure protein

Table 7. Purified Aspergillus fungal allergens

Table 8. The cross reactivity of AVS-PAb with mycelia extracts by ELISA assay

Table 9. The cross reactivity of AVL-PAb with mycelia extracts by ELISA assay

\section{List of Figures}

Figure 1. Effect of homogenization on ELISA response of A. versicolor spores 35

Figure 2. Effect of buffer solution on ELISA response of spore extracts 36

Figure 3. Efficiency homogenization on ELISA response of AV cell 39

Figure 4. Comparison of the polycolonal antibodies through development stages 41

Figure 5. Purification of AVS-PAb 42 
Figure 6. Purification of AVL- PAb

Figure 7. Optimization of ammonium sulfate concentration for AVS separation $\quad 44$

Figure 8. Optimization of ammonium sulfate concentration for AVL separation $\quad 45$

Figure 9. Optimization of $\mathrm{NaCl}$ concentration to remove AVS from Q sepharose column

Figure 10. Optimization of $\mathrm{NaCl}$ concentration to remove AVL from $\mathrm{Q}$ sephorose column

Figure 11. CBB stain of AVS and AVL after ion exchange chromatography

Figure 12. AVS after ion exchange chromatography comparing immunoblot and CBB stain gel

Figure 13. Identification of AVS by immunoblot

Figure 14. AVL after ion exchange chromatography: comparing immunoblot and CBB stained gel

Figure 15. Identification of AVL by immunoblot

Figure 16. AVS preparation after gel filtration

Figure 17. Immunoblot of AVS preparation after gel filtration

Figure 18. CBB stain of AVS with different amount of protein 58

Figure 19. Silver stain of AVS with $3 \mathrm{mg}$ protein from each purification step

Figure 20. Immunoblot of AVS fraction from each purification step ( $3 \mu \mathrm{g}$ of protein)

(1506 serum used as the primary antibody)

Figure 21. Immunoblot of AVS fractions from each purification step ( $3 \mu \mathrm{g}$ of protein) (AVS-PAb used as the primary antibody)

Figure 22. SDS-PAGE molecular weight standard curve 
Figure 23. Chromatograph of gel filtration standards

Figure 24. Standard curve of gel filtration chromatography

Figure 25. Gel filtration chromatography of AVS 


\section{Introduction}

\subsection{Fungi}

Fungi are eukaryotic, saprophytic organisms that among other ecological roles, degrade organic materials. The fungi are divided into three groups based on their characteristic reproductive structures. These groups are known as the Ascomycetes, the Basidiomycetes and the Phycomycetes (Kendrick, 2001). Fungi cells are bounded by rigid cell walls that are usually composed of chitin fibrils embedded in a matrix of $\beta-D$ glucans and mannans. Cell walls may be coated externally with waxes or hydrophilic extracellular polysaccharides that carry various levels of antigenic specificity. Fungi are ubiquitous organisms, which make up approximately $25 \%$ of the earth's biomass (Miller, 1992). Their primary ecological role is biodegradative. Fungi commonly damage various man-made articles including building materials (Flannigan \& Miller, 2001). To digest food, fungi excrete enzymes into the environment to break down complex carbon compounds. These enzymes are some of the major fungal allergens (NAS, 2000). While processing organic material, the fungi produce many secondary metabolites, some of which are highly toxic (antibiotics, mycotoxins). These compounds may accumulate in the mycelium, in the spores, or be excreted into the environment. The primary mode of fungi reproduction is by airborne spores. Fungal spores are major fraction of both outdoor (Womiloju, et.al., 2003) and indoor large-particle aerosol (Foto, et. Al., 2005) Fungi also colonize manmade environments, releasing both spores and metabolic material.

\subsection{Indoor Fungi}

\subsubsection{Indoor sources:}


Fungi are always present in dust and on surfaces. One of the largest Canadian housing studies was undertaken in Wallaceburg, Ontario found over 270 fungal species in dust; however only $\sim 20$ species were commonly found on indoor building materials. Fungal growth occurs only in the presence of moisture. The nature of the building materials, available nutrients and temperature affect the amount of water required to permit fungal growth. Microbiologists call the amount of available water in a building material "water activity" $\left(a_{w}\right)$ (Flannigan \& Miller, 2001). For example, Chang et al (1996) studied the growth of Penicillium chryrsogenum (a fungus with an intermediate optimal $a_{w}, 0.79-0.85$ ) on several kinds of HVAC duct lining materials. With relatively concentrated inoculums, there was minimal growth at relatively low substrate water activities; however, extensive growth was reported when the humidity approached $100 \%$. Other fungi, such as Wallemia sebi can grow at low water activities $\left(\mathrm{a}_{\mathrm{w}}, 0.69-0.75\right)$ and, at the other end of the spectrum, Stachybotrys chartarum can only grow at near water saturation levels $\left(a_{w}, 0.91-0.93\right)$ (Flanningan \& Miller, 2001).

Various genera grow and reproduce on different building materials and contents (from food to paper-faced gypsum wallboard), at different substrate water contents and temperatures, and thus fungal growth can occur in a wide range of habitats. Constituents of indoor air are determined by both outdoor and indoor sources. Likewise mold types and concentrations indoors are primarily a function of outdoor fungi. Higher concentrations of outdoor molds and other fungi are found where trees, shrubs and landscape irrigation occurs close to exterior building walls. Iverson \& Pedersen (1990) investigated of water-damaged buildings in Denmark. They reported that the microfungi isolated most frequently from gypsum board and other building materials were species of 
Aspergillus and Penicillium. These genera were present in 56 to $68 \%$ of samples, respectively. The species encountered most frequently were, $P$. chrysogenum, $A$. versicolor and $S$. chartarum. Studies of fungi on gypsum wallboard conducted in the Unite States and Canada indicated a generally similar picture although the diversity was greater because of a much greater range of temperature conditions that occur in these larger countries. The most common species isolated included fungi requiring high moisture requirements such as Chaetomium globosum, S. chartarum, Memnoniella echinata, and Cladosporium sphaerospermum, species such as Eurotium herbariorum, and fungi such as $P$. chrysogenum and $A$. versicolor (Flannigan \& Miller, 2001).

\subsection{Population Health Issues}

In 1991, the first large studies on damp housing and health in Canada were published which involved 15,000 children and 18,000 adults in 30 communities. Study shows Canadians spend $92 \%$ of their time indoors. Between $10 \%$ and $30 \%$ of the homes in North American have moisture problems leading to mold growth. This means that occupants are breathing large number of fungal spores, which are found in indoor air (Miller, 1992)

As explained above, the fungi involved comprise a narrow group of 20-30 species of fungi. Many of the fungi that are common including $S$. chartarum and $P$. autantiogriseum were deemed responsible for human and animal intoxication due to their mycotoxins (Miller, 1992).

\subsubsection{Mold increase respiratory disease}


Health Canada began studying the impact of housing on health in the early 1980s. By the end of the decade, two important studies suggested that mold and dampness were important determinants of respiratory health. A study found that mold and dampness in homes resulted in increased asthma and increased upper respiratory disease in 4,600 children from six cities in the northern US. Two Canadian studies reported similar findings in 15,000 children and 18,000 adults (Miller, 1992). Overall, mold contamination is associated with $50 \%$ increase in asthma and a $60 \%$ increase in upper respiratory disease. It was estimated that the maximum attributable risk for asthma caused by mold exposures in Canada was about 20\% (Soto-Quiros et al., 1998). In a major report on asthma, the Institute of Medicine of the US National Academy of Sciences was able to conclude that mold in buildings was an important public health issue (NAS 2000).

In a University of Virginia study, Alternaria sensitivity was also a significant independent risk factor for asthma in school children in Charlottesville, Virginia, and Los Alamos, New Mexico, but not in Albemarle County, Virginia. Of 1218 children born on the Isle of Wight, $6 \%$ of the 918 4-year-old children tested had positive skin tests to Alternaria and or Cladosporium. In these 61 children, a positive test to Alternaria was associated with a diagnosis of asthma (NAS 2000). In Costa Rica, where the prevalence of childhood asthma is $20-30 \%$, dust mite, cat, Alternaria, and Cladosporium-specific IgEs contribute to asthma (Soto-Quiros et al., 1998). In a case-control study in Denver, Colorado, acute asthmatics in the age rang of 3-16 where tested negative controls using RAST to document specific IgE levels. The researchers found that $45 \%$ of asthmatics versus $4 \%$ of controls had high IgE to Alternaria (NAS 2000). In a large (6394 children) 
questionnaire-based study, Peat et al. (1995) showed that among asthmatic children, Alternaria sensitivity rates are higher inland New South Wales, but the damp coastal climate, sensitivity to dust mites is more prevalent. In 4295 , children and young adults in the second United States National Health and Nutrition Examination Survey (NHANES II) cohort, asthma was associated with sensitivity to dust mite and Alternaria exposure (NAS 2000). Retrospective investigation of asthma deaths in teenagers revealed that a large majority had positive skin tests to Alternaria, and the authors concluded that sensitivity to Alternaria is a risk for severe asthma and death (NAS 2000).

$\mathrm{Su}$ et al. (1992) described relationships between indoor measured levels of culturable Aspergillus and asthma in Topeka, Kansas school children. Culture plate impactors were used to collect short "grab" samples in homes of children recruited through the public schools. The relationship between Aspergillus and asthma symptoms was non-linear, possibly reflecting the different species of Aspergillus that are common in these indoor environments. In the Garrett et al. (1998) reported, associations between measured concentrations of fungal spores and culturable fungi, there was a correlation between these observed indicators of dampness and mold presenc with fungal sensitivity, and observered respiratory symptoms. Eighty households with 148 children (36\% asthmatic) were sampled six times for airborne fungi. Penicillium exposure was associated with asthma, and Aspergillus exposure with atopy. Cladosporium and Penicillium exposure were also found to be associated with the presence of fungal allergy. Exposure measures to specific fungi showed a stronger association with these symptoms than did dampness indicators.

Other studies comparing indoor fungi presence and asthma $\mathrm{t}$ found that the fungal 
levels in the homes of asthmatics to be significantly higher whencompared to homes of control subjects. Li and Hsu (1997) compared culturable fungi in homes of 46 asthmatic children, 20 atopic (presumably non-asthmatic) children, and 26 non atopic controls. Although fungal concentrations were highest in the asthmatic and control homes, Cladosporium concentrations were higher in asthma homes than in control homes. In a study by Horak et al. (1996), Aspergillus, and total fungal concentrations were higher in homes of asthmatics than in control homes. These kinds of studies are compromised by the fact that families of asthmatic children often take measures to reduce exposure to allergens.

Connections between animal allergens, dampness, and asthma have been drawn in several studies. Symptoms related to asthma were more common in dwellings with house dust mites and visible signs of dampness or microbial growth. Positive skin tests to dust mite allergens were more prevalent among occupants of damp houses (Iversen \& Pedersen, 1990). It was also reported that a combination of high-dose exposure to cat or dog allergen, environmental tobacco smoke, and damp housing was significantly associated with asthma.

Williamson et al. (1997) report a correlation between mold growth indicators and asthma (196 age-and sex-matched subjects). It was reported in 1999 that allergy to fungi (Cladosporium or Alternaria) was more prevalent in damp homes (9.3\% versus 3.9\%) and fungal sensitivity was related to current asthma. Among a population sample of 873 children, Strachan (1988) studied respiratory symptoms, measured pulmonary function, and evaluated the home environment for reported dampness or mold presence. Wheezing in the past year was most closely associated with visible mold. The prevalence of lower- 
respiratory symptoms (any cough, phlegm and wheezing) was increased among those reporting dampness or mold compared with those not reporting dampness or mold as follows: $38 \%$ versus $27 \%$ among current smokers, $21 \%$ versus $14 \%$ among ex-smokers, and $19 \%$ versus $11 \%$ among nonsmokers.

\subsubsection{Mold associated allergic disease}

Fungi produce an enormous array of proteins that are potentially allergenic. Many fungi produce different allergens with a wide range of potencies. Allergy can be defined as an untoward response to a specific antigen mediated by an immunological reaction. This complex immunoligical response may take many different forms. The most common clinical manifestation of an allergic reaction to molds is IgE-mediated response, represented by symptoms of rhinitis, conjunctivitis and asthma.

The earliest report of an allergic response to molds was documented in 1726 . In 1873, Blackley (Block 1953) described "bronchial catarrh" and severe chest tightness flowing inhalation of Penicillium spores. Since then, research has shown that exposure to fungal products generates a wide range of adverse responses, including hypersensitivity. Reactions occur not only to the spores and mycelia of fungi, but also to the mycotoxins produced as secondary metabolites, the volatile organic compounds emitted by growing fungi, enzymes produced by the organisms, and (1-3)- $\beta$-D-glucan, a component of the fungal cell wall (Flannigan \& Miller, 2001).

\subsubsection{Mold Allergy}

\subsection{Allergy to airborne molds}


The symptoms tend to follow a seasonal profile, with certain times of the year (spring and late summer/early autumn) being more severe than others. The molds involved are dominant and ubiquitous. Allergy to these molds is frequently associated with allergic reactions of pollen and prolongation of the hay fever season for sufferers. The diagnosis of this type of allergy is facilitated by numerous commercially available extracts. A fundamental problem with commercial preparations is that they are not well defined or well characterized (Esch, 2004).

There is little or no seasonal fluctuation of symptoms exists in patients with allergies to primarily indoor species. A large number of different fungal species fit into this category. Each habitat is associated with it its own characteristic fungal species, but the commercially available range of extracts remains incomplete and therefore insufficient to categorically exclude the possibility of fungal allergy (Horner, 2005).

\subsubsection{Allergenic species of fungi and their allergens}

A large number of fungi have been identified in the medical literature as being implicated in allergic disease. The spore states of many anamorphic Ascomycetes are probably allergenic (NAS 2000). Allergenic differences clearly exist between different species of fungi within the same genus. Strain-to-strain and batch-to-batch variations occur in the processing of allergenic extracts. Allergens may be recovered from both spore and mycelia materials. The differences between spore and mycelium-derived allergens have yet to be fully explored.

Alternaria alternata is common in outdoor air and has been a much studied allergenic fungus. The major allergenic fraction of $A$. alternata is heterogeneous and can 
induce allergenic reactions at very low concentrations in sensitized individuals. Thirty two antigens and 19 different allergens (Day \& Ellis, 2001) have been identified. However, only one allergen, Alt a1, is important in humandisease. The phyloplane fungus Cladosporium herbarum has also been studied extensively and about 60 antigens have been found in extracts (Day \& Ellis, 2001). Two major allergens, Clah and Clah 2 have been described. These allergens have been found to vary widely from strain to strain, at lease under the laboratory conditions used by investigators in the past.

Two antigens have been purified for $A$. fumigatus. The $18 \mathrm{kDa}$ antigen was isolated from mycelium and the $20 \mathrm{kDa}$ from culture filtrates; the latter one is the major allergen. Culture filtrate extracts of this allergen demonstrate more allergenic potential than those extracted from mycelium. (Latge et al., 1991)

\subsubsection{Allergic clinical syndromes}

Fungi and fungal products cause a wide range of hypersensitivity responses, some which have been recognized for centuries and others that have been only been recently identified as clinical entities.

\subsection{Allergic rhinitis}

Rhinitis occurs as an emergence of nasal mucous membrane inflammation leading to nasal discharge, sneezing, and congestion. Mold spores are an important cause of nasal allergy because they are so widespread. The particles are much smaller than pollen and are easily inhaled and absorbed. In a large study (3371 patients), $25.8 \%$ of those with a diagnosis of rhinitis were sensitized to molds. Of those, a combined diagnosis of asthma 
and allergic rhinitis was observed (Flannigan et al., 2001).

\subsection{Allergic bronchopulmonary aspergillosis}

Allergic bronchopulmonary aspergillosis (ABPA) is a pulmonary disease that is caused by $A$. fumigatus that has colonized the lower respiratory tract. Patients are usually atop individuals with asthma, and those individuals with cystic fibrosis are particularly at risk The $A$. fumigatus spores are inhaled and trapped in the respiratory tract, where they can grow at body temperature in airway mucus. The spores germinate to form mycotoxins within the segmental airways. In predisposed individuals, antigen-specific $\operatorname{IgE}, \operatorname{IgG}$ and $\operatorname{IgA}$ antibodies are produced, leading to an array of immunological responses (Flannigan et al., 2001).

\subsection{Allergic fungal sinusitis}

Allergic fungal sinusitis (AFS) is a recently recognized clinical entity that occurs in up to $7 \%$ of patients with chronic sinusitis. APF occurs in patients who are atopic and have chronic sinusitis (DeShazo, 1995). Many have had multiple sinus operations by the time of diagnosis. Patients are usually young and immuno-comprimised.

\subsubsection{The theory of the allergic respiratory response to fungi}

The immune system, which has a series of complex cellular and humoral elements, is capable of distinguishing between many types of molecular structures (antigens) to protect the host. Exposure to agents such as fungi or products derived from them may cause injury. Host defense is accomplished by both cellular and humoral elements that act 
interdependently, while barriers, including mucous membranes and skin, form the first line of defense against these pathogens (Flannigan et al., 2001).

\subsubsection{Cellular components}

The fundamental unit of the immune system is the antigen-specific lymphocyte. The lymphocytes are the part of the immune system which allows the host to recognize a wide range of antigens.

Lymphocytes are produced from stem cells located in the bone marrow. Lymphocyte populations consist of B lymphocytes, $\mathrm{T}$ lymphocytes, and null cells. B lymphocytes mature in bone marrow; and $\mathrm{T}$ lymphocytes migrate to the thymus to mature. As lymphocytes develop and differentiate into B or T cells, they re-arrange sections of DNA that house the genes responsible for producing antigen specific receptors. The cells are then cloned, sharing the same antigen specificity. A foreign antigen entering the body will stimulate only those lymphocytes whose lymphocytes and receptors recognize determinants expressed by that antigen. Following the binding of lymphocyte and antigen, colonial proliferation occurs in a process known as recognition. A smaller number of lymphocytes not involved in neutralizing the antigen remain in the system and are presensitized. Subsequent exposures to the antigen may result in more rapid and intense response derived from immunologic memory (Hobart, 1975).

\subsubsection{Humoral Components}

The humoral elements of the immune system consist of antibodies (immunoglobulins) and the complement system. The complement system may act in 
concert with antibodies or may exert its effect directly with the offending agent.

\subsection{Antibodies}

B lymphocytes, in their plasma cell, produce glycoprotein receptors known as immunoglobulins. These compounds play a central role in the recognition of antigenic structures. Since many different plasma cell clones are responsible for the production of antibodies, they are markedly variable in specificity.

Antibody molecules have two identical light chains and two identical heavy chains bound together by disulfide bonds. When the antibody molecules are digested with enzymes fragments, the molecules are broken down into their functional units: (1) two antigen-binding fragments (Fab) and (2) one crystal liable fragment $(\mathrm{Fc})$. The Fab portion of the Ig molecule is responsible for binding specifically to an antigen and the Fc portion interacts with cells of the immune or complement system (Flannigan et al., 2001).

The unique properties of the Fc fragment divide immunoglobulin into five major forms, each with different types of heavy chains: $\operatorname{IgG}, \operatorname{IgA}, \operatorname{IgM}, \operatorname{IgD}$, $\operatorname{IgE}$. In a secreted form in the serum, antibodies recognize and eliminate antigens.

IgE-mediated responses are central to the immediate hypersensitivity (allergic) reaction as these antibodies bind to the surface of mast cells and basophils via high affinity receptors. Allergens are antigens that bind to these $\operatorname{IgE}$ molecules.

\subsection{Complement System}

Complement is a series of approximately 20 proteins and is one of the main mediators of inflammatory reactions. Activation of the pathway generally occurs at sites 
of antibody (IgM or IgG) immune complexes. These antigen-antibody complexes may also activate the alternative pathway as can certain microbes and parasites. The major functions of complement include the lysis of susceptible target cells, the opsonization of antigens for phagocytosis by macrophages and neutrophils, as well as the production of inflammatory peptides.

Hypersensitivity is an exaggerated antigen-induced response that occurs following re-exposure to an antigen. This inappropriate response is heterogeneous and is subject to the variable characteristics of individuals.

\subsubsection{Mediators of Allergic Response}

Recent interest and the growing concern over immediate hypersensitivity reactions have led to a directed research effort in the field of biochemical mediators of allergic reactions. The pathophsiological processes occurring during allergic reactions are a consequence of a complex array of mediators released from mast cells or basophiles following antigen-IgE bridging. There are a diverse number of cells responsible for the production of mediators and increasing information on the structural composition of various lipid mediators.

The concentrations of these mediators increase during delayed chronic inflammatory tissue changes. Allergic mediators may be grouped as follows: (1) spasmogenic/ vasoactive, (2) chemotactic, (3) enzymatic, and (4) structural proteoglycans.

\subsection{Aspergillus}

The fungus Aspergillus is widely distributed from the arctic region to the tropics. 
Aspergillus species are frequently found in air and soil as discussed above, also some members of Aspergillus are often found growing indoors. A. fumigatus and some other species are pathogenic species, in some cases resulting in the invasive disease aspergillosis. Aspergillus spores were among the first to be recognized aeroallergens, and these fungi cause several other diseases.

\subsubsection{Biodeterioration}

Species of Aspergillus are capable of utilizing an enormous variety of organic material for food because of their ability to produce a large number of enzymes. Under humid conditions, Aspergillus species grow on leather and cloth fabrics, reducing their value and imparting musty odor to shoes and clothing. Several species are frequently found on grains and exposed foodstuffs where they cause decay and the subsequent loss affected food stuffs (Schmechel et al., 2005).

\subsubsection{Mycotoxins}

Aspergillus species produce toxic compounds, the most well known being aflatoxins. Aflatoxin is an IARC class 1 carcinogen produced by strains of $A$. flavus and $A$. parasiticus and some other uncommon fungi species. The best known toxic metabolites of $A$. fumigatus are mainly fumigaclavines $\mathrm{A}, \mathrm{B}, \mathrm{C}$, and $\mathrm{D}$, spinulosin and tremorgenous toxins (e.g. verruculogen). A. niger strains produce toxic metabolites belonging to malformins A1, A2, B1, B2, C and oxalic acid. On building materials, strains of $A$. versicolor produce the toxin class $2 \mathrm{~A}$ carcinogenic sterigmatocystin (NAS, 2000). 


\subsubsection{Allergic Reactions}

Many species of Aspergillus produce dry, hydrophobic spores that are easily inhaled. Due to their small size, about $70 \%$ of spores of $A$. fumigatus are able to penetrate into the trachea and primary bronchi and close to $1 \%$ into alveoli. The inhalation of spores of Aspergillus is a known health risk (Harber et al., 1996). A. clavatus causes the occupational hypersentivity pneumonitis commonly known as malt worker's lung. (Harber et al., 1996)

\subsection{Aspergillus versicolor}

A. versicolor is commonly found in soil, hay cotton and dairy products. As the name of this fungus implies, $A$. versicolor may be of various colors. This species is very common and displays great variability in colony pattern and size

A. versicolor is studied in the context of building related illnesses, because it is one of the most frequently occurring species found in damp indoor environments and is known to be the major producer of the hepatotoxic and the carcinogenic mycotoxin sterigmatocystin (Barnes et al., 1994). In a study of water-damaged building materials, analyses of wallpaper and fiberglass wallpaper naturally contaminated with $A$. versicolor revealed sterigmatocystin and 5-methoxysterigmatocystin (Nielsen et al., 1999). Tuomi and coworkers found sterigmatocystin in $24 \%$ of bulk samples of moldy interior finishes from Finnish buildings with moisture problems, ranging from 0.2 to $1,000 \mathrm{ng}$ per $\mathrm{g}$ of sample (Tuomi et al., 2000). 


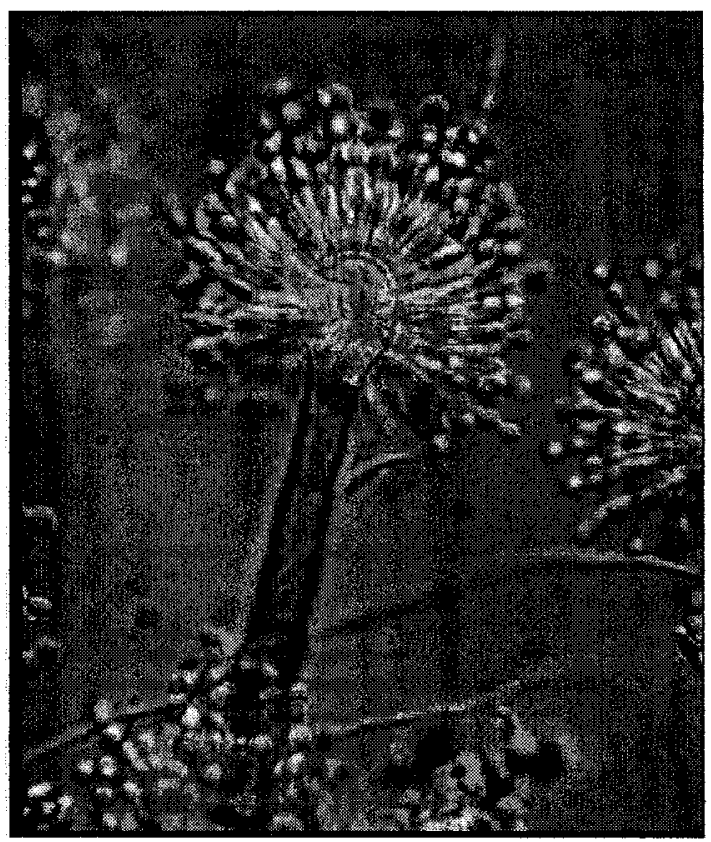

Aspergillus versicolor coniduim with spores

A. versicolor is often detected in moisture-damaged materials and in the air of moisture-damaged buildings (Graveson et al., 1999; Flannigant \& Miller, 2001). Studies have found it to be an indicator microbe for moisture damage (Samson et. al., 1994). Aspergilllus spores are small in size (aerodynamic size, 2.0-3.6 um) (Juha \& Komulainen, 2002) and can be inhaled deeply into lungs. Moreover, the spores are possible carriers of nonvolatile mycotoxins, glucan and as also illustrated in the present work, allergens (Sorenson, 1999).

\subsection{Purification of fungal allergens}

Major allergens are those to which the majority of allergic subjects react. All currently purified allergens are proteins or glycoproteins. Traditionally, allergens have been purified by standard liquid chromatography. More recently, high-performance liquid 
chromatography (HPLC), fast protein liquid chromatography and preparative electrophoresis have also been utilized (Horner et al., 1995).

In the past, the potency and reactivity of fractionated or purified allergen were assessed by RAST (RadioAllergyoAorbent Test) inhibition. While potency is still measured by RAST inhibition, immunoprinting and HPLC procedures are used more commonly to assess purity and determine physicochemical properties. (Horner et al., 1995)

\subsubsection{Monoclonal antibodies (Mabs)}

MAbs allow the isolation, characterization, and precise identification of specific fungal allergens (Lehrer \& Salvaggio, 1990). A significant advantage of hybridoma technology is that MAbs can be produced against allergens that are present in mixtures of antigens. This reduces the need for allergen purification but requires more extensive screening of clones. Once obtained, MAbs may be used to purify allergens by affinity chromatography (Chapman, 1989). Theoretically, MAbs have unlimited availability, can be stored easily, and provide precise and sensitive tools to test allergen structures and standardize allergen preparations. Currently, MAbs are being used to develop immunoassays for quantifying fungal allergens in environmental samples, and MAbs are also being used to define specific epitopes. The application of MAb technology will probably be most useful in standardization of extracts. At present, human sera containing allergen-specific antibodies are still used in many of these assays. Complications arise because of the inherent variability of the human antibody response. Since MAbs are homogeneous, they will greatly reduce the variability of these immunoassays. (Horner et 
al., 1995)

\subsubsection{Test Methods for Purified Extracts}

The simplest and most direct method of determining the allergenic activity of an extract is skin testing of allergic subjects. To evaluate nonspecific reactions, atopic individuals who are not sensitive to the test allergen must be included for study. Ideally, the investigator would prefer to have an in vitro assay for testing purified extracts in which test conditions could be controlled more tightly. In vitro testing is a very active research area. The RAST is the most widely used assay. The RAST and RAST inhibition are excellent methods to monitor purification procedures. RAST inhibition provides a quantitative estimate of the allergenic activity of a purified sample, but one cannot determine qualitatively which allergen has been detected. Direct challenges of sensitized subjects with small doses of extracts can confirm biological activity and allow estimates of the proportion of allergenicity that is due to the single, purified allergen. Gel electrophoresis techniques, including isoelectric focusing and SDS-PAGE, are very sensitive assays that are now widely used to assess allergen purity. Immuno-blots of gels can be probed with polyclonal sera to detect possibly present allergens. These methods have been used traditionally to characterize allergens purified from crude extracts. The rapidly increasing number of cloned allergen genes will allow production of large quantities of recombinant allergen. Recombinant proteins can be produced as a fusion with other proteins (or peptides) that can facilitate purification.

\subsubsection{Standardization of Extracts}


Previous reviews discuss the background and problems of allergen standardization (Bush \& Yungiger, 1987). More than 200 fungal extracts, produced by 12 manufacturers, are commercially available in the US. None are standardized, and all are mixtures of multiple antigenic and allergenic components. Standardization must be established among extracts to ensure consistent composition and activity. Skin tests and/or in vitro procedures may be the basis for standardization but must permit the determination of biological potency of extracts from a variety of source materials and manufacturers. Skin testing is a sensitive measure of the potency of an extract, but the responses of different populations to a selected allergen may vary and the reaction observed in a single individual may not always appear to be reproduced. These problems are one of the significant disadvantages of skin testing. In addition, skin testing reveals nothing about individual allergens in complex mixtures such as crude fungal extracts. (Horner et al., 1995)

Efforts at establishing this standardization will benefit greatly from the use of MAbs (Lehrer \& Salvaggio, 1990). Historically, one of the greatest needs for achieving standardization was a source of homogeneous antibodies to well-defined allergens. Sera from humans or animals with allergen-specific antibodies are always of limited supply, and animal anti-sera may not recognize the same epitopes as those of humans. Polyclonal anti-sera with the appropriate specifications are also difficult to produce in the large volumes required for standardization efforts. The use of MAbs can overcome these problems; they can be exquisitely specific and are available in large quantities, and with proper safeguards, cells that produce them are virtually immortal (Horner et al., 1995).

At present, there are three independent systems for the expression of extract potency. 
Two systems, biological units and allergy units (AU), are based on skin test reactivity. The biological unit system originated in Scandinavia and is widely accepted in Europe. It compares the skin test reactivity of the test extract with the reactivity of histamine chloride (1 mg/ml) (Platts-Mills, 1985). The allergy unit system developed by the United States Food and Drug Administration is based on intradermal skin testing with threefold dilutions of extract. The intradermal end point is expressed as the number of threefold dilutions required diluting the extract such that it will produce a 50 -mm-wide skin reddening reaction (Salvaggio et al., 1993). International units, the unit of measure of the third system, are used for international standard preparations (ISPs). This system was established by the Subcommittee for Allergen Standardization of the International Union of Immunologic Societies and conforms to the requirements of the World Health Organization. The international unit is an arbitrary measure assigned to an ISP. Extracts compared with the ISP can be assigned a given number of international units on the basis of the relative potency of the extract and the ISP. Although in vitro quantization of extracts by a RAST is more practical, the superiority of standardized extracts must still be demonstrated by their usefulness for skin tests (Horner et al., 1995).

Defined allergens are also useful to generate Mabs, which can be used to measure environmental allergen concentrations. In this way, threshold exposures can be determined, and the efficacy of allergen reduction strategies can be documented and implemented (Horner et al., 1995). 


\section{MATERIALS AND METHODS}

\subsection{Cultures}

Aspergillus versicolor DAOM 235361 was the principal strain studied in this project. The strain was isolated from indoor air sample collected in Winnipeg, MB by Paracel Laboratories Ltd. (Ottawa, Ontario). The strain was identified by Dr. J. David Miller and confirmed by DAOM. The strain was transferred onto sterile $2 \%$ malt extract agar (Difco) slants and stored at $5^{\circ} \mathrm{C}$. Cultures were prepared as follows. A slant was macerated in sterile ultrapure water from which $2.5 \%$ aliquot was used to inoculate $2.8 \mathrm{~L}$ Fernbach flasks each containing $560 \mathrm{~mL}$ and $2 \mathrm{~L}$ Erlenmeyer flasks containing $400 \mathrm{~mL}$ of a medium developed for the accumulation of proteins and peptides (Traber et al. 1989). The medium comprised $50 \mathrm{~g}$ maltose, $8 \mathrm{~g}$ peptone, $5 \mathrm{~g}$ yeast extract, $0.75 \mathrm{~g} \mathrm{KH}_{2} \mathrm{PO}_{2}, 0.5 \mathrm{~g}$ $\mathrm{MgSO}_{4}-7 \mathrm{H}_{2} \mathrm{O}$ and $0.067 \mathrm{~g} \mathrm{CaCl}_{2}-2 \mathrm{H}_{2} \mathrm{O}$ per $\mathrm{L}$ ultrapure water. The cultures were put on a rotary shaker at $220 \mathrm{rpm}$ and $25^{\circ} \mathrm{C}$ for two days in the dark. All cultures were filtered through cheese cloth using a Buchner funnel. The filtrate from each flask was collected and stored at $5^{\circ} \mathrm{C}$ for later processing. The mycelium was rinsed twice with ultrapure water, dried under vacuum, wrapped in aluminum foil and frozen.

Spores were produced on rice cultures adapted from the method of Murad et al. (1993). Rice (50 g Uncle Bens was placed in $500 \mathrm{ml}$ wide-mouth Erlenmeyer flasks, 30 $\mathrm{ml}$ of water was added and the mixture was autoclaved for $30 \mathrm{~min}$. Cultures were inoculated and incubated at $25^{\circ} \mathrm{C}$ in the dark for 3 weeks and then dried at $30^{\circ} \mathrm{C}$ in an oven. Spores were harvested by physical removal of spores from the rice grains and stored in vials at $-20^{\circ} \mathrm{C}$. 
Liquid cultures and spores were produced as above to produce mycelial extracts for specificity tests. The fungi tested included Alternaria alternata $27-1^{*}$, Aspergillus ochraceous 12-7-3, A. flavus 12-7-4, A. fumigatus 31, A. niger 5869-6, A. penicillioides 5053-15, A. unguis 9507-5, A. ustus 12-7-3, A. versicolor DAOM** 235361, A. versicolor 43-2, Cladosporium cladosporioides 48-1, Epicoccum nigrum 51-2, Chaetomium globosum 317-1, Memnoniella echinata DAOM 235365, Paecilomyces varioti DAOM 235357, Penicillium commune 21-1, P. expansum DAOM 235358, P. corylophylum 12-7-3, P. chrysogenum DAOM 234056, P. spinulosum 12-7-1, Talaromyces varioti XXX, Scopulariopsis brevicaulis 5869-3, Stachybotrys chartarum (DAOM 235364), S. chlorohalonata (***ATCC 201863), Wallemia sebi 12-7-2.

*Paracel Laboratory Ltd; **National Mycological Herbarium, Ottawa; ***American Type Culture Collection, Manassas, VA.

\subsection{Antibodies}

Immunoblots were done with two sources of antibodies. The first included human sera from atopic patients provided by ProGene Ltd., a large research-clinical laboratory in Lenexa, KS. These had been screened using Pharmacia ImmunoCAP® reagents for response to various fungi during clinical diagnostic testing. After the tests were completed, the samples were stripped of identifiers and provided to the Miller lab for research purposes. Work on the preliminary identification of the target proteins in this thesis was performed by Dr. Jiangping Xu and J. David Miller. Briefly, extracts from cultures from a large array of single spore strains of $A$. versicolor were screened on 
immunoblot with several dozen human sera from the above source. This permitted the identification of two proteins to which there was a common response in all atopic human sera and found across a wide geographic array of strains. Using a representative, good producer of both proteins (DAOM 235361), polyclonal antibodies were both raised in separate goats. Approximately $1 \mathrm{mg}$ of each protein was cut from electrophoresis gels and was inoculated into two goats resulting in the production of polyclonal antibodies with attenuated response to spore-borne proteins other than the target protein. The resulting antibodies, present in the terminal bleeds, were used in this project. A comparison of the performance of the polyclonal through the stages was performed in the present work.

Two polyclonal antibodies are used in this project: AVL anti-A. versicolor polyclonal hereafter AVL-PAb and AVS anti-A. versicolor polyclonal (hereafter AVS-PAb).

One of the most reactive human sera (1506) was also used for these experiments.

\subsection{Affinity purification of anti-A.versicolor goat polycolonal antibodies}

A protein G column (BioLynx Inc.) was used to isolate antibodies from goat sera. To $2 \mathrm{ml}$ of goat serum, an equal volume of saturated ammonium (AS) sulfate was added yielding a $50 \%$ saturated solution. This was left at $4^{\circ} \mathrm{C}$ overnight. This was centrifuged $17,400 \times g$ for $10 \mathrm{~min}$ after which the lipid layer was removed and the supernatant discarded. The pellet was dissolved in $2-4 \mathrm{ml}$ of PBS solution. The material was desalted by dialysis using membrane tubing (Spectra/Por 1 Membrane, Spectrum; molecular weight cut off $6-8 \mathrm{kDa}, 40 \pm 2 \times 25.5 \mathrm{~mm}$ ) with a several changes of ultrapure water. The Protein G column was washed with 10 column volumes of PBS buffer. The dialyzed solution was applied to the Protein $G$ column and incubated the column at room 
temperature for $2 \mathrm{~h}$ (or overnight at $4^{\circ} \mathrm{C}$ ). The column was then washed with $50 \mathrm{mM}$ phosphate buffer until there was no protein in the effluent based on the UV response at $280 \mathrm{~nm}$. Before elution, $50 \mu \mathrm{L}$ of $1.5 \mathrm{M}$ Tris/HCL buffer, $\mathrm{pH} 8.8$ was added to the collection tubes (this neutralized the sample washing off the column). The column was eluted at $0.4 \mathrm{ml} / \mathrm{min}$ with $0.1 \mathrm{M}$ glycine- $\mathrm{HCl}, \mathrm{pH} 2.7$; fractions were collected at $1 \mathrm{~mL} /$ tube.

\subsection{Protein assays}

Lowry Assay (Lowry et al. 1951) reagents were prepared as follows. Typically 50g $\mathrm{Na}_{2} \mathrm{CO}_{3}$ was dissolved in $400 \mathrm{ml}$ deionized water, $0.5 \mathrm{~g}$ potassium sodium tartrate in 50 $\mathrm{ml}$ water and $0.25 \mathrm{~g}$ of $\mathrm{CuSO}_{4}$ in $50 \mathrm{ml}$ water. One $\mathrm{ml}$ of phenol reagent (Sigma, St.Louis, MO) was diluted by adding $8 \mathrm{ml}$ water. An aliquot $(0.2 \mathrm{ml}$ of sample diluted in water $)$ and $0.2 \mathrm{ml}$ folin mixture was mixed well and left at room temperature for $10 \mathrm{~min}$ followed by the addition of diluted phenol solution. This was heated to $55^{\circ} \mathrm{C}$ in a water bath for $5 \mathrm{~min}$ and then placed in ice. The OD was determined at $650 \mathrm{~nm}$.

When the protein concentration was $>20 \mu \mathrm{g} / \mathrm{ml}$, the bicinchoninic (BCA) method was used to determine the protein concentration with the Micro BCATM Protein Assay Kit (Pierce) according to the manufacturer's instructions. Briefly, $250 \mu \mathrm{L}$ of working reagent was placed into a small tube, $250 \mu \mathrm{l}$ of sample (distilled water was used to dilute the sample) and mixed well. The tube was covered and incubated at $60^{\circ} \mathrm{C}$ water bath for $1 \mathrm{~h}$ when it was put on ice. The OD was determined at $562 \mathrm{~nm}$. A standard curve was used to estimate the protein concentration. 


\subsection{Protein extraction}

\subsubsection{Extracellular proteins:}

Experiments to optimize the ammonium sulphate concentration during the extraction were conducted following this general protocol. Typically, 2 L cold acetone (Caledon, $\mathrm{ON}$ ) were added to $1 \mathrm{~L}$ of culture filtrate resulting in a $50 \%$ acetone solution that was kept at $-20^{\circ} \mathrm{C}$ overnight to precipitate proteins. Some non-protein precipitate was removed by centrifugation (Beckman Coulter Avanti J-E) at $17,400 \times \mathrm{g}$ for $5 \mathrm{~min}$ at $-4^{\circ} \mathrm{C}$. Additional cold acetone was added to make a $75 \%$ solution, again left at $-20^{\circ} \mathrm{C}$ overnight and centrifuged for an additional $5 \mathrm{~min}$ as above. The precipitated proteins were again precipitated and recovered by $75 \%$ of acetone. The pellet was removed and dissolved in 50mM Tris/HCL buffer (pH7.5). Sufficient AS was slowly dissolved to reach $60 \%$ saturation. This was stirred in an ice bath for $10-15 \mathrm{~min}$ to ensure that all the salt was dissolved. The resulting solution was left overnight at $4^{\circ} \mathrm{C}$ to allow the proteins to precipitate. The solution was centrifuged for $10 \mathrm{~min}$ a $17,100 \times \mathrm{g}$ as above. Additional AS was to bring the solution to $70 \%$ saturation and the material left overnight at $4^{\circ} \mathrm{C}$. The resulting suspension was centrifuged for 10 minutes as above and resulting pellets were dissolved in $50 \mathrm{mM}$ Tris/HCL buffer, $\mathrm{pH} 7.5$ and stored at $4^{\circ} \mathrm{C}$.

\subsubsection{Intracellular proteins:}

Experiments to optimize the AS concentration during the extraction were conducted following this general protocol. An extraction buffer was made by dissolving $6.057 \mathrm{~g}$ of Trizma base (Sigma) in deionized water made to $1 \mathrm{~L}$. The $\mathrm{pH}$ was adjusted to 7.5 with $6 \mathrm{~N}$ 
$\mathrm{HCl}$ (Fisher Scientific) followed by the addition of $0.5 \mathrm{~g}$ Tween 20 (Sigma-Aldrich). Typically, 20g of freeze dried mycelium were added $200 \mathrm{ml}$ of extraction buffer in a $500 \mathrm{ml}$ beaker, which was vortexed and kept on ice for at least $10 \mathrm{~min}$ to permit the mycelium to dehydrate. The container resulting suspension was homogenized with a Polytron (Kinematica, Switzerland) at maximum speed for $5 \times 3$ min with 10 min intervals. The resulting homogenate was transferred to a $250 \mathrm{ml}$ centrifuge tube and centrifuged $17,400 \times \mathrm{g}$ for $10 \mathrm{~min}$ as above from which the supernatant was placed in a $500 \mathrm{ml}$ beaker. AS was added slowly wwhile stirring on ice bath to bring the solution to $40 \%$ saturation, making sure that all salt was dissolved. The resulting solution was kept at $4^{\circ} \mathrm{C}$ overnight. The solutionl was then centrifuged for $10 \mathrm{~min}$ at $17,400 \times \mathrm{g}$ at $4^{\circ} \mathrm{C}$. and the pellet removed and re-disolved in 50mM Tris buffer, $\mathrm{pH} 8.8$ and stored for future use at $4^{\circ} \mathrm{C}$. Additional ammonium sulfate was then added to the supernatant to increase the salt concentration from $40 \%$ to $60 \%$, again with stirring on ice bath. The resulting solution was kept overnight at $4^{\circ} \mathrm{C}$. The resulting suspension was centrifuged for $10 \mathrm{~min}$ at in $20 \mathrm{ml}$ centrifuge tubes, the supernatant was discarded and the pellet was dissolved as above.

\subsection{Ion exchange chromatography}

The target proteins were known to be a negatively-charged in the buffers used for the intracellular ( $\mathrm{pH}$ 8.8) and extracellular ( $\mathrm{pH}$ 7.5) fractions. Anion exchange chromatography was performed using a Q-Sepharose system (Q Sepharose Fast Flow Anion exchanger, wet bead size: $45-165 \mu \mathrm{m}$, pre-swollen in $20 \%$ ethanol) placed in a $1 \mathrm{x}$ $17 \mathrm{~cm}$ ion exchange column. 
Experiments to optimize the $\mathrm{NaCl}$ concentration in the buffer fractionation process were conducted using the following protocol. Isolation of the extracellular target protein (hereafter AVS) was performed as follows. The anion exchange column was washed with $50 \mathrm{ml}$ buffer $\mathrm{pH} 7.5$. An aliquot $(10 \mathrm{ml})$ of the sample was loaded (approximately $80 \mathrm{mg}$ protein) at a flow rate $1 \mathrm{ml} / \mathrm{min}$. The column was washed with $50 \mathrm{mM}$ buffer $\mathrm{pH} 7.5$. The UV optical density of the wash was determined to be zero at $280 \mathrm{~nm}$. The protein was stripped off with $50 \mathrm{ml} \mathrm{NaCl}$-Tris buffer solution with increasing $\mathrm{NaCl}$ concentrations. Fractions were collected at $0.1 \mathrm{M} \mathrm{NaCl}$-Tris buffer, $0.15 \mathrm{M} \mathrm{NaCl}$-Tris buffer, $0.2 \mathrm{M} \mathrm{NaCl}$ Tris buffer and $0.3 \mathrm{M} \mathrm{NaCl}$ - Tris buffer, respectively. The antigenic AVS protein fractions were collected at $0.2 \mathrm{M} \mathrm{NaCl}$-Tris buffer concentration at flow rate of $1 \mathrm{ml} / \mathrm{min}$ in a $5 \mathrm{ml} /$ tube fraction with a fraction collector (RediFrac collector, Amersham Bioscience) The salt content of the buffer was changed from $0.3 \mathrm{M}$ to $1.0 \mathrm{M}$ to remove the remaining proteins from the columns. The column was washed with buffer $\mathrm{pH} 7.5$ until the OD 280 $\mathrm{nm}$ of the wash was zero.

Experiments to optimize the $\mathrm{NaCl}$ in buffer fractionation process were conducted following the following general protocol. Isolation of the intracellular protein (hereafter AVL) was done in a similar fashion except the $\mathrm{pH}$ of the loading and washing buffers was pH 8.8. The majority of the antigenic AVL protein came off in $0.15 \mathrm{M} \mathrm{NaCl}$ buffer.

\subsection{Gel filtration chromatography}

Gel filtration was used to further purify the proteins. Sephacryl S-200-HR (Sigma)

was chosen as an intermediate separation gel. The gel was slowly loaded onto a 
Sepharose column $(96 \times 1.6 \mathrm{~cm})$ and allowed to settle down for $24 \mathrm{~h}$ at $4^{\circ} \mathrm{C}$. A solution consisting of $0.2 \mathrm{M} \mathrm{NaCl} / 50 \mathrm{mM}$ Tris/ $\mathrm{HCl}$ buffer $\mathrm{pH} 7.5$ was allowed to flow through the column at $0.4 \mathrm{~mL} / \mathrm{min}$ for $\geq 12 \mathrm{~h}$ to prepare the column. A $0.5 \mathrm{ml}$ concentrated aliquot of protein fraction sample (approximately $1.5 \mathrm{mg}$ protein) was slowly loaded onto the Sepharose column using the $0.1 \mathrm{M} \mathrm{NaCl}$-Tris buffer at $0.4 \mathrm{ml} / \mathrm{min}$. After loading, two additional $1 \mathrm{ml}$ portion of buffer was added to load the proteins on the column. The $0.1 \mathrm{M}$ $\mathrm{NaCl}$-Tris buffer was used to run the column at flow rate $0.4 \mathrm{ml} / \mathrm{min}$. The buffer flow was maintained and fractions were collected with a fraction collector at $1 \mathrm{ml} /$ tube in $1 \times 10 \mathrm{ml}$ test tubes. Proteins were identified by immunoblotting (see following).

\subsection{Sodium Dodecyl Sulfate-Polyacrylamide Gel Electrophoresis (SDS-PAGE)}

Purity and molecular weight of the protein were estimated using SDS-PAGE. The proteins were separated by SDS-PAGE $(8.5 \times 8 \mathrm{~cm}$ vertical slab gels $)$ with $10 \%$ acrylamide gel using the Laemmli running buffer system (Laemmli, 1970); Tris, 15g, glycine (Sigma) 72g, SDS (USB, Cleveland), $10 \mathrm{~g}$ to $1 \mathrm{~L}$ deionized water). The $10 \%$ acrylamide gel was made by mixing $2.0 \mathrm{~mL}, 1.7 \mathrm{ml}$ of $30 \%$ acrylamide (Bio-Rad), $1.3 \mathrm{ml}$ of $1.5 \mathrm{M}$ Tris/ $\mathrm{HCl}$ buffer, $\mathrm{pH} 8.8,50 \mu 110 \% \mathrm{SDS}, 50 \mu \mathrm{l}$ of $10 \%$ ammonium persulfate (APS; USB) and $5 \mu \mathrm{L}$ TEMED (N,N,N',N'-Tetramethylethylenediamine; USB). The stacking gel was made by mixing $1.4 \mathrm{ml}$ deionized water, $0.33 \mathrm{~mL} 30 \%$ acrylamide mix, $0.25 \mathrm{ml} \mathrm{1.0} \mathrm{M} \mathrm{Tris/HCl} \mathrm{buffer} \mathrm{(pH} \mathrm{6.8),} 20 \mathrm{ul} 10 \%$ ammonium sulfate, $20 \mu \mathrm{L} 110 \%$ APS and $2 \mu \mathrm{L}$ TEMED. Before application to the gel, protein samples were mixed 4:1 (v/v) with a $5 \times$ loading buffer (15\% SDS, $50 \%$ glycerol (EDH), $0.05 \%$ bromophenol blue (USB), 5\% $\beta$-mercaptoethanol (Sigma) and 30\% $624 \mathrm{mM}$ Tris/HCl, $\mathrm{pH} 6.8$ ), boiled for 5 
min and placed on ice to cool. Electrophoresis was performed using a mini VE Vertical Electrophoresis System in an Amersham Biosciences electrophoresis tank connected to a Power Pac 1000 gel electrophoresis power supply (Bio-Rad). Experiments were carried out at $100 \mathrm{~V}$ for $20 \mathrm{~min}$ followed by $200 \mathrm{~V}$ for $50 \mathrm{~min}$ until the bromophenol blue dye reached $1 \mathrm{~cm}$ from the bottom of the gel.

The gel was stained with GelCode Blue Stain (CBB stain; Rockford, IL). In the case that the protein concentration was too low for $\mathrm{CBB}$ stain, silver stain was done by using the PlusOne silver staining kit (Amersham Biosciences). The gel was fixed for $30 \mathrm{~min}$ in fixation solution (10\% acetic acid, $25 \%$ methanol in deionized water). The gel was then silver stained with silver as follows. The gel was treated for $30 \mathrm{~min}$ with $25 \mathrm{ml}$

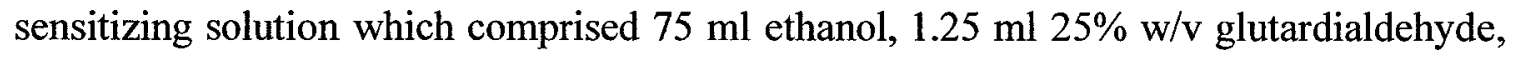
$10 \mathrm{ml} \mathrm{5 \%} \mathrm{w/v} \mathrm{sodium} \mathrm{thiosulphate,} 17 \mathrm{~g}$ sodium acetate to $250 \mathrm{ml}$ deionized distilled water. The gel was washed three times for $5 \mathrm{~min}$ with deionized water. The staining solution was $25 \mathrm{ml} 2.5 \% \mathrm{w} / \mathrm{v}$ silver nitrate solution, $0.1 \mathrm{ml} 37 \% \mathrm{w} / \mathrm{v}$ formaldehyde $(37 \%$ w/v) to $250 \mathrm{ml}$ deinized water. The gel was again washed for $1 \mathrm{~min}$ with two portions of deionized water. The developing solution made by adding 6.25 sodium carbonate, 0.05 $\mathrm{ml}$ formaldehyde to $250 \mathrm{ml}$ deionized water with stirring. The reaction was stopped by a solution comprising 3.65 g EDTA- $\mathrm{Na}_{2} \mathrm{H}_{2} \mathrm{O}$ made to $250 \mathrm{ml}$ deoinzed water.

\subsection{Immunoblotting}

Immunoblot analysis can normally detect one protein in a mixture of any number of proteins for which mammalian antibodies are present. The proteins were separated by SDS-PAGE and were transferred to a Hybond-PVDF membrane (Amersham Biosciences) 
with an electro- transfer unit (Hoefer miniVE, Amersham Biosciences) in Towbin buffer. (12 g Trizma base, $57.6 \mathrm{~g}$ glycine, $4 \mathrm{~g}$ SDS in $200 \mathrm{ml}$ ethanol to $1 \mathrm{~L}$ with deionized water). The electro-transfer was carried out at a constant current of $400 \mathrm{~mA}$ for 30 minutes in ice bath. After the transfer, the membrane was incubated in $1 \%(\mathrm{w} / \mathrm{v})$ bovine serum albumin (BSA; Sigma) dissolved in TBST buffer (typically $1 \mathrm{~g}$ of BSA was dissolved in $100 \mathrm{ml}$ of TBST mixing for $1 \mathrm{~h}$ ). TBST buffer was made by dissolving $60.5 \mathrm{~g}$ Trizma base, $87.6 \mathrm{~g} \mathrm{NaCl}, 5.6 \mathrm{~g}$ of Tween $20(0.05 \%)$ in $600 \mathrm{~mL}$ deionized water, adjusted to $\mathrm{pH} 7.4$ with $1 \mathrm{M} \mathrm{HCl}$ to $1 \mathrm{~L}$ deionized. The membrane was incubated with various human sera (1506) or AVS-PAb or AVL-PAb goat sera in 1\%(w/v) BSA/TBST for $1 \mathrm{~h}$ (respectively). The membrane was washed $3 \times 5$ min with TBST buffer and incubated with the secondary antibody alkaline phosphatase (AP) 1:10,000 conjugated mouse antihuman (Sigma) or 1:2500 AP conjugated rabbit anti-goat IgG (Sigma) in 1\% BSA/TBST buffer at room temperature for $1 \mathrm{~h}$. The membrane was then washed 3 times for $5 \mathrm{~min}$ with TBST buffer. The proteins with immunological activity were stained by incubating the membrane with the Sigma liquid substrate system (BCIP/NBT (5-Bromo-4-chloro-3indolyl phosphate dipotassium/nitrotetrazolium blue chloride) for membranes.

\subsection{Immune affinity purification}

CNBr-activated Sepharose 4 Fast Flow (0.5g; Amersham Bioscience) was added to a $5 \mathrm{ml}$ minicolumn. Sepharose was swollen in cold $1 \mathrm{mM} \mathrm{HCl}$ and the column was washed with at least $10-15$ volumes of $1 \mathrm{mM} \mathrm{HCl}$. Sufficient coupling buffer was added to bring the $\mathrm{pH}$ to 8.3 . The coupling buffer was $0.5 \mathrm{M} \mathrm{NaCl} / 0.1 \mathrm{MNaHCO}_{3}, \mathrm{pH} 8.3$. AVS samples from the ion exchange column were dialyzed in membrane tubing. The dialyzed AVS 
samples were added to the mini column containing coupling buffer. The column was shaken at room temperature for $2-4$ hours or overnight at $4^{\circ} \mathrm{C}$. The buffer in the mini column was removed and excess proteins were washed away with at least 5 column volumes of coupling buffer. The OD of the flow through was checked at $280 \mathrm{~nm}$ to monitor the reaction. Tris/HCL $0.1 \mathrm{M}$ buffer, $\mathrm{pH} 8.0$ was added into the mini column and incubated for $2 \mathrm{~h}$ to block remaining active groups. The column was then washed using a low salt $(0.5 \mathrm{M} \mathrm{NaCl} / 0.1 \mathrm{M}$ acetate acid (Anachemia) buffer (pH 3-4) and high salt buffer (0.5 M NaCl/0.1M Tris/HCl, $\mathrm{pH} 8.0)$.

AVS-PAB prepared as above was added to the mini column with PBS buffer. This was then incubated at room temperature for $2 \mathrm{~h}$ or overnight at $4^{\circ} \mathrm{C}$. The mini column was washed with binding buffer until there was no protein in the effluent, confirmed by checking the optical density at $280 \mathrm{~nm}$. The mini column was washed with $50 \mathrm{mM}$ phosphate buffer, $\mathrm{pH}$ 7.4. The collection tubes were prepared as above by adding $50 \mu \mathrm{l}$ of 1.5 M Tris/HCl buffer $\mathrm{pH}$ 8.8. At a flow rate of $0.4 \mathrm{ml} / \mathrm{min}$, the column was eluted with $0.1 \mathrm{M}$ glycine- $\mathrm{HCl}, \mathrm{pH} 2.7$ as above.

\subsection{Molecular weight determinations}

The native molecular weight of the proteins was estimated from a plot of log molecular weight versus $R_{f}$ of the SDS-PAGE standards. A low molecular weight calibration kit for SDS electrophoresis (Amersham Biosciences) was used as molecular weight markers with the molecular weight range $14-97 \mathrm{kDa}$ including phosphorylase $\mathrm{B}$ (97 $\mathrm{kDa})$, albumin $(66 \mathrm{kDa})$, ovalbumin $(45 \mathrm{kDa})$, carbonic anhydrase $(30 \mathrm{kDa})$, trypsin inhibitor $(20.1 \mathrm{kDa})$ and lactoalbumin $(14.4 \mathrm{kDa})$. SDS PAGE was performed as above. 
The native molecular weight of AVS was determined from a plot of log molecular weight versus the elution volume of gel filtration standards. A molecular weight calibration kit (Sigma) was used with a molecular weight range of 12-2,000 kDa including blue dextran $(2000 \mathrm{kDa})$ beta-amylase $(200 \mathrm{kDa})$, alcohol dehydrogenase $(150$ $\mathrm{kDa})$, BSA (66 kDa), carbonic anhydrase (29 kDa) and cytochrome c (12.4 kDa).

\subsection{Cross-reactivity experiments using AVL-PAB and AVS-PAB}

The general protocol was as follows. Nunc-Immuno MaxiSorp Plates were used throughout (Nunc, Rochester, NY). Protein samples were directly diluted with coating buffer (50 mM carbonate-bicarbonate $\mathrm{pH} 9.6)$ in wells with $100 \mu \mathrm{L}$ of protein per immunoplate well. The plate was then incubated on a microplate shaker overnight at $4^{\circ} \mathrm{C}$. Subsequent manipulations were done at room temperature. The plate was washed $3 \times 5$ min with $150 \mu \mathrm{l}$ PBST between incubations. The PBST was made by dissolving $80 \mathrm{~g}$ $\mathrm{NaCl}, 26.8 \mathrm{~g} \mathrm{Na}_{2} \mathrm{HPO}_{4}-7 \mathrm{H}_{2} \mathrm{O}, 2 \mathrm{~g} \mathrm{KCl}, 2.4 \mathrm{~g} \mathrm{KH}_{2} \mathrm{PO}_{4}$ and $1.0 \mathrm{~g}$ Tween 20 in $600 \mathrm{ml}$ deionized water. The $\mathrm{pH}$ was adjusted to 7.4 with $1 \mathrm{M} \mathrm{HCl}$ and the solution was diluted 1 $\mathrm{L}$ with deionized water. The coated plate was blocked with $100 \mu \mathrm{L}$ of $2.0 \% \mathrm{BSA} / \mathrm{PBS}$ buffer for $1 \mathrm{~h}$ and incubated with $100 \mu \mathrm{L}$ of a 1:1000 dilution of AVS-PAb or 1:500 AVSPAb goat sera in $1 \% \mathrm{BSA} / \mathrm{PBST}$ for $1 \mathrm{~h}$. Finally the plate was incubated with $100 \mu \mathrm{L}$ of AP conjugated rabbit anti-goat IgG at a dilution of 1:2000 in 1\% BSA/PBST for $1 \mathrm{~h}$. The color was developed by adding $100 \mu 1$ of $3,3,5,5^{\prime}$ tetramethybenzidine liquid substrate for ELISA (TMD; Sigma), with shaking for $10 \mathrm{~min}$ and adding $50 \mu \mathrm{L}$ of $0.5 \mathrm{M} \mathrm{H}_{2} \mathrm{SO}_{4}$ solution to stop the colour development. The plate was then read in microplate spectrophotometer at $450 \mathrm{~nm}$. 
The ELISA assay was used to optimize the primary antibody dilution for both AVS and AVL protein. One $\mu \mathrm{g} /$ well AVS (or AVL) protein with coating buffer was applied to the microplates. The AVS (or AVL) goat sera was applied to the plate from $1 / 50$ (or $1 / 10$ for AVL), followed by serial $1 / 2$ dilutions. AP conjugated rabbit anti-goat IgG at a dilution of 1:2000 in 1\% BSA/PBST was used as secondary antibody as above. The colour reaction was initiated by adding $100 \mu \mathrm{l}$ of 3,3', 5,5' tetramethybenzidine liquid substrate for ELISA (TMD; Sigma). $50 \mu \mathrm{L}$ of $0.5 \mathrm{M} \mathrm{H}_{2} \mathrm{SO}_{4}$ solution was used to stop the colour development. The plate was read at $450 \mathrm{~nm}$.

\subsection{Purified AVS}

Standard curves derived by ELISA for $60-70 \%$ ammonium sulphate precipitation and material off the ion exchange column were prepared over a five log dilution. (0.001 to $100 \mu \mathrm{g} /$ well). Because the amount of protein was low in some fractions, concentration of the secondary antibody was increased (dilution of the anti-goat IgG was 1:200).

\subsection{Spore extracts}

A protocol was developed to conduct ELISA measurements of AVS and AVL in spore extracts. These involved two steps: examine appropriate extraction methods for spores, and, determine whether the extraction buffer was appropriate. A modification of the protocol was made for ELISA experiments conducted with extracts of fungal spores. These extracts were known to be different from the others used for ELISA to the extent that they are not enriched for proteins compared to the other compounds present. Using spores from $A$. versicolor DAOM 235361, $1.0 \mathrm{mg}$ were carefully weighed using a Mettler 
163 analytical balance $( \pm 0.02 \mathrm{mg})$ into two $2 \mathrm{ml}$ vials. An aliquot $(0.1 \mathrm{ml})$ of PBS buffer was added. One was allowed to stand at room temperature for $10 \mathrm{~min}$. The other, containing a polystyrene bead was milled for 15 min using Spex-Certiprep mixer mill (model 5100, Metuchen, NJ), $0.1 \mathrm{ml}$ buffer added and mixed and allowed to stand for 10 $\min$.

To test the effect of buffer on the ELSIA result for the spore tests, extracts derived from samples extracted with the mixer mill were dissolved in three different buffers. These included PBS, PBST and coating buffer. The use of the mixer mill resulted in a dramatic improvement in antigen yield and was used in all subsequent experiments with spores (Figure 1). The use of PBS was chosen as the preferred extraction solvent (Figure 2). The AVS PAb was used in both tests.

Similar extracts from 14 species for fungi common in the built environment and one additional strain of $A$. versicolor prepared as above were examined for cross-reactivity. The arithmetic and geometric mean protein contents of the spore extracts used were 16.6 and $14.9 \mathrm{ng} / \mathrm{ml}$, respectively, meaning that $\sim 1.7 \mathrm{ng}$ protein was added per well (Table 1 ). 


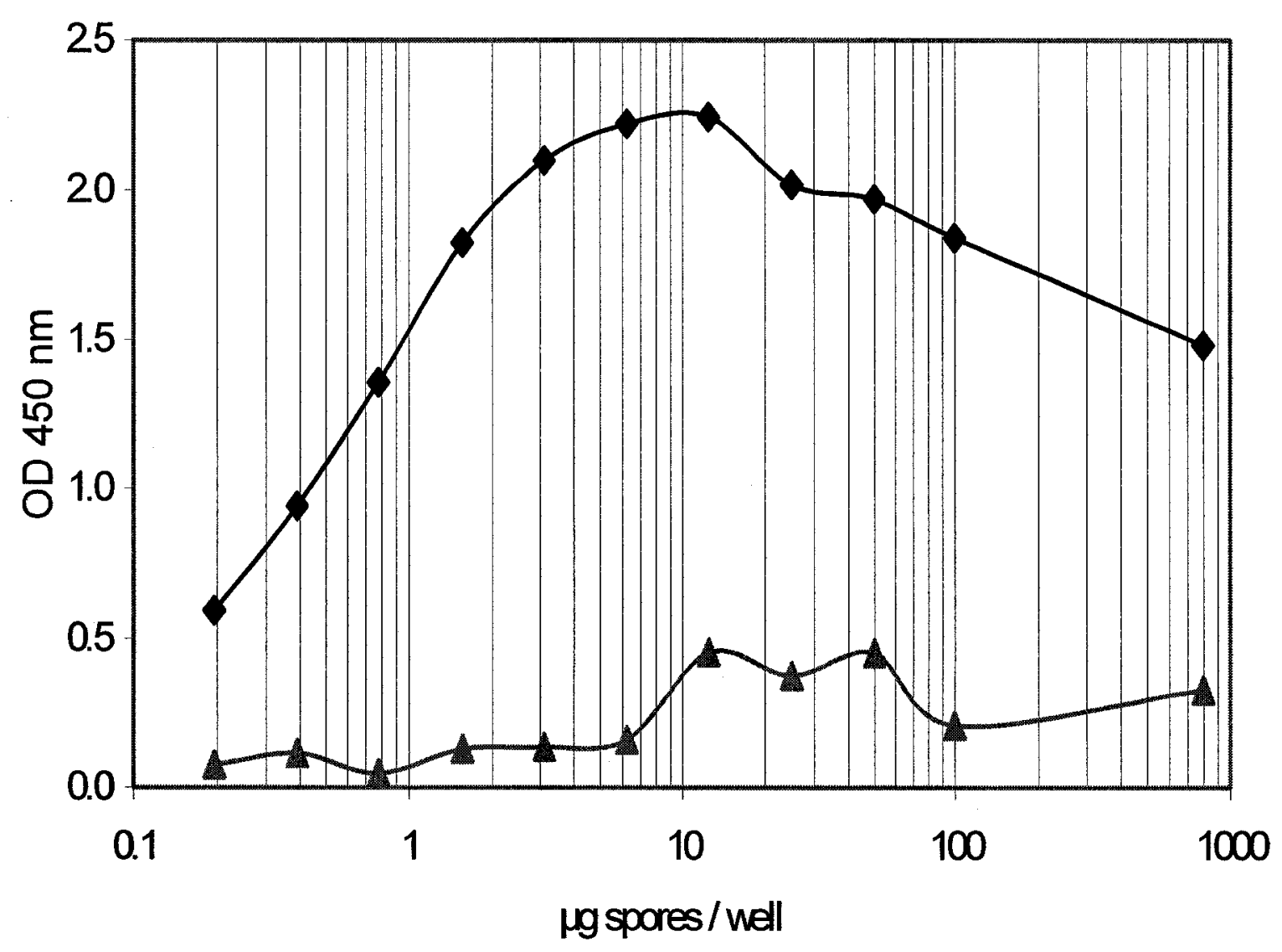

- - AV 235361 spores treated with mixer-mill

- A - AV 235361 spores

Figure1. Effect of homogenization on ELISA response of spores of

A. versicolor 235361 


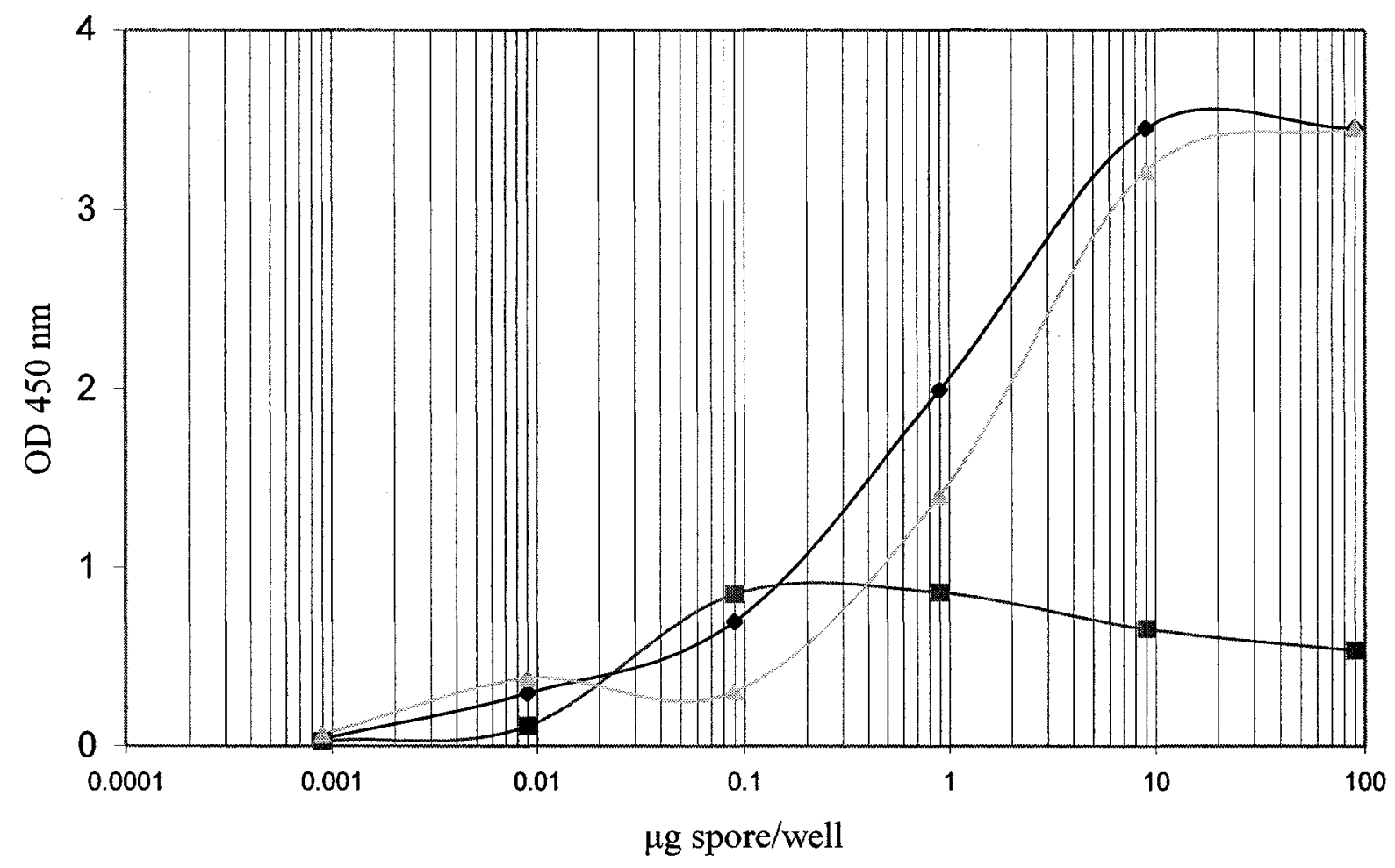

- - PBS buffer

-匹- PBST buffer

- $\Delta$ - coating buffer

Figure 2. Effect of buffer solution on ELISA response of spore extracts 
Table1. Spores mean protein concentration in cross activity ELISA assay

\begin{tabular}{lc}
\hline \multicolumn{1}{c}{ Fungus } & $\begin{array}{c}\text { Spore protein concentration } \\
\mathrm{ng} / \mathrm{ml}\end{array}$ \\
\hline Aspergillus niger & 30.64 \\
A. flavus & 15.18 \\
A. funigatus & 18.28 \\
A. ochraceus & 4.84 \\
A.ustus & 15.51 \\
Eurotium amstelodomi & 12.38 \\
Penicillum chrysogenum & 21.66 \\
P. expansum & 8.94 \\
Paecilomyces varotii & 14.86 \\
Scorulopsis brevicaulis & 6.85 \\
Stachybotrys chartarum & 18.41 \\
S. chlorohalonata & 26.63 \\
Talaromyces flavus & 15.65 \\
Aspergillus versicolor 235361 & 23.29 \\
\hline Arithmetic mean protein contens & \\
\hline Geometric mean protein contents & \\
\hline
\end{tabular}

mycelium: $0.09 \mu \mathrm{g} /$ well

\subsection{Mycelial extracts}

Using freeze dried mycelium from $A$. versicolor DAOM 235361, $1.0 \mathrm{mg}$ were carefully weighed and extracted as above comparing a 10 min extraction in PBS with the extraction with the mixer-mill as above, followed by ELISA using AVL PAb as the 
primary antibody. The use of the mixer mill resulted in a very large increase in antigen yield (Figure 3). This was proven to be not necessary because more cells were available than spores. The freeze dried cells were extracted with Tris $\mathrm{HCl}$ using the Polytron as above and screened as above with AVS-PAb and AVL-PAb, respectively. An aliquot of $20 \mu 1$ of AVS or AVL extracts, respectively, were diluted with $80 \mu 1$ coating buffer in the wells. The amount of protein added was $20 \mu \mathrm{g} /$ well for each extract.

\subsection{Identification of antigenic protein using CBB stained gels and immunoblots}

CBB stained gels and immunoblots were performed to visualize proteins and determine which protein was reactive to the human sera. An aliquot of $20 \mu \mathrm{L}$ protein sample from the ion exchange column $(2.7 \mathrm{mg} / \mathrm{ml}$ protein) was applied to the gel. Gels were typically run at $100 \mathrm{~V}$ for $20 \mathrm{~min}$ followed by $200 \mathrm{~V}$ for $50 \mathrm{~min}$ The gel was stained with GelCode Blue Stain. Two protein bands around $45 \mathrm{kDa}$ were visualized in the region of the target protein. To clarify which was antigenic, the two bands were cut off from the CBB stained gel and transferred to membrane by using a needle to punch a hole beside the band. After transfer the membrane was put into $25 \%$ methanol solution with was used to decolorize the gel. The membrane was subject to immunoblot analysis with human 1506 sera as the primary antibody. The band that reacted to the antibody was antigenic.

All results represented through a minimum of two replications of three separate experiments. 


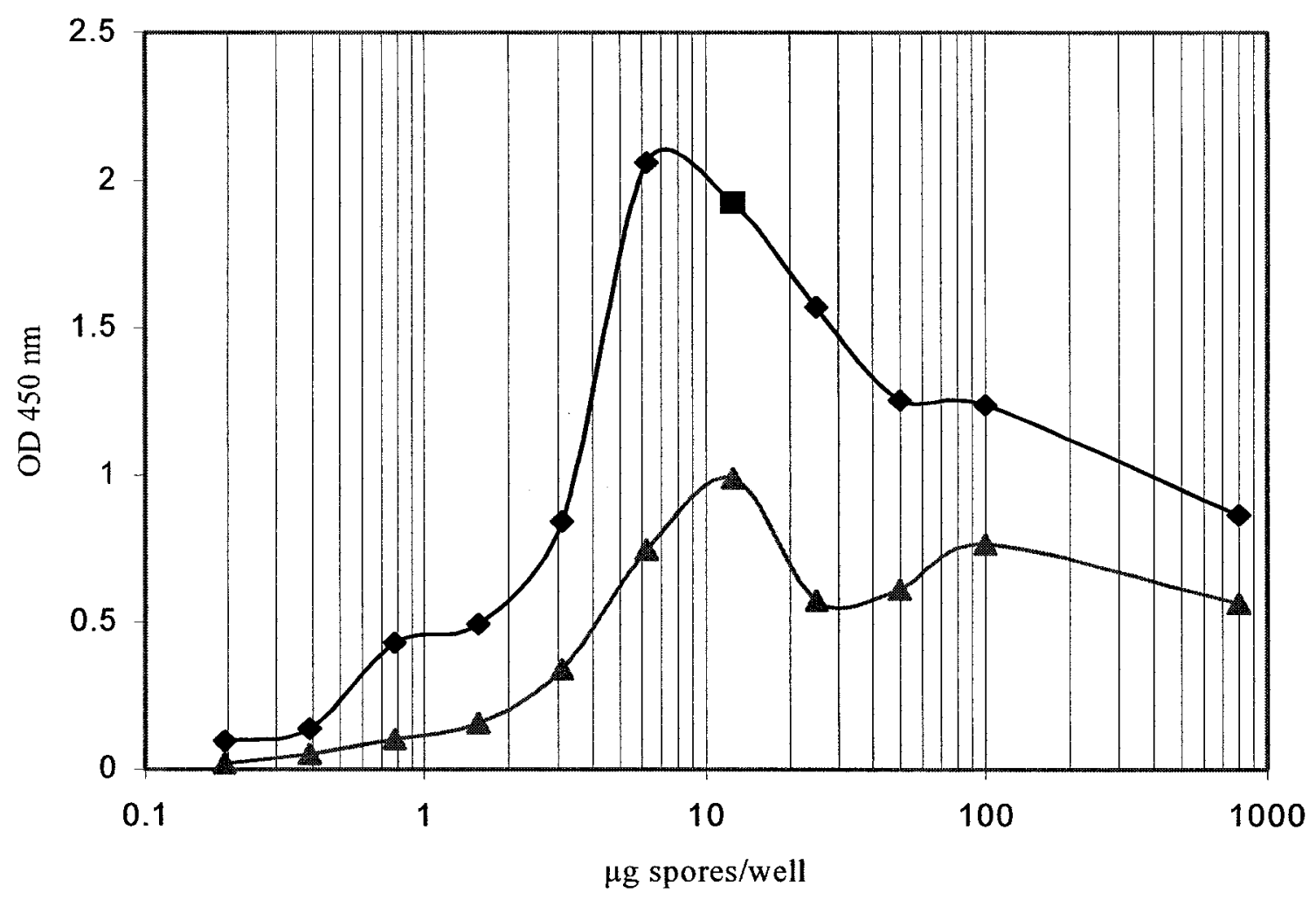

-- n - AV 235361 spores treated with mixer-mill

-A - AV 235361 untreated Spores

Figure 3 Efficiency of homogenization on ELISA response of AV cell 


\section{RESULTS}

\subsection{Polyclonal antibody}

A comparison of the AVS-PAb through the development stages (spores, boosted with pure AVS) is shown on Figure 4. The spore immunization elicited antibodies to many proteins including the target protein AVS. The titres of most of these antibodies were reduced or eliminated with time after the AVS boost notably excepting AVS itself and a several additional proteins. This means that the AVS protein is present in intact spores produced as a cultural artifact. The results of similar experiments with the AVL protein were materially the same.

The effect of the purification of the AVS- PAb and AVL-PAb on the quality of immunoblots is shown in Figures 5 and 6, respectively. In both cases, the immunoblots enabled clearer visualization of the target protein and the purified antibody was used throughout these experiments.

\subsection{Protein isolation}

\subsubsection{Separation of antigenic proteins from Aspergillus versicolor}

Separation and purification of the antigenic proteins identified in the intracellular (AVL) and extracellular (AVS) compartments of $A$. versicolor. The proteins were separated and concentrated through a series of steps. The cellular proteins were extracted in acetone and salted out. The protein was further fractionated by stepwise AS precipitation. The results of these experiments are shown in Figures 7 and 8. The number of proteins from the extracellular fraction recognized by 1506 serum was small and the 


\section{Figure 4. Comparison of the polycolonal antibodies through development stages}
A. MW marker
B after immunization with spores
C after immunization with AVS cut from gels
1. extract of $A$. versicolor spores
2. AVS acetone precipitation
3. AVS material from ion exchange column 


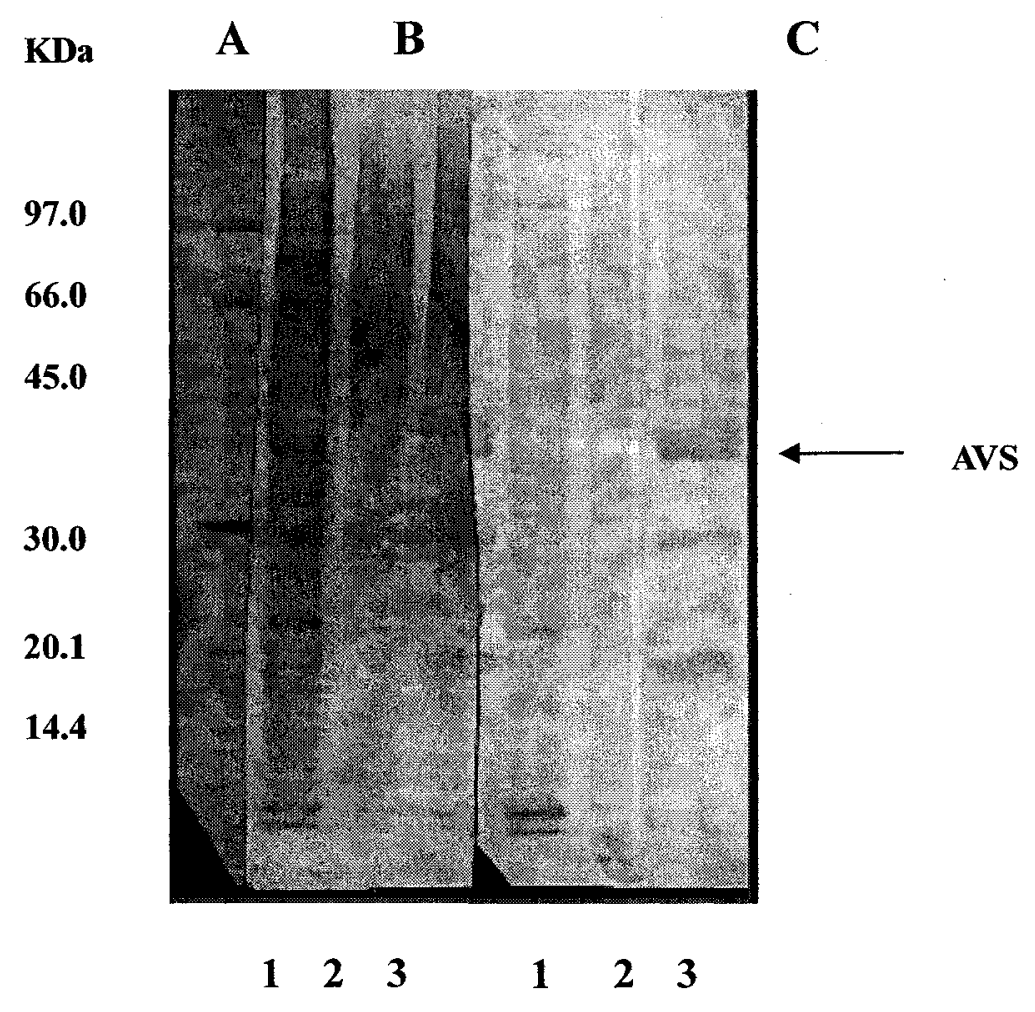


Figure 5. Purification of AVS-PAb

1, 3: 1506 serum

2: AVS-PAb before purification

4: AVS-PAb after protein G purification

5,6: AVS-PA after CNBr-Sepharose purification 


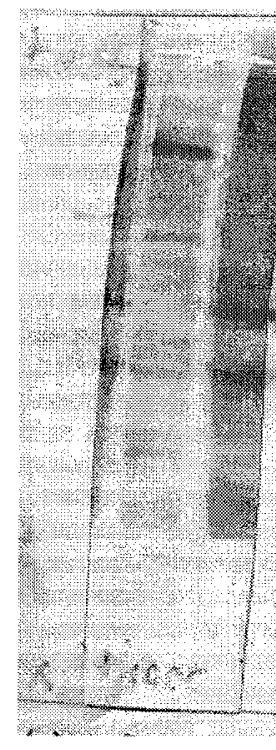

12

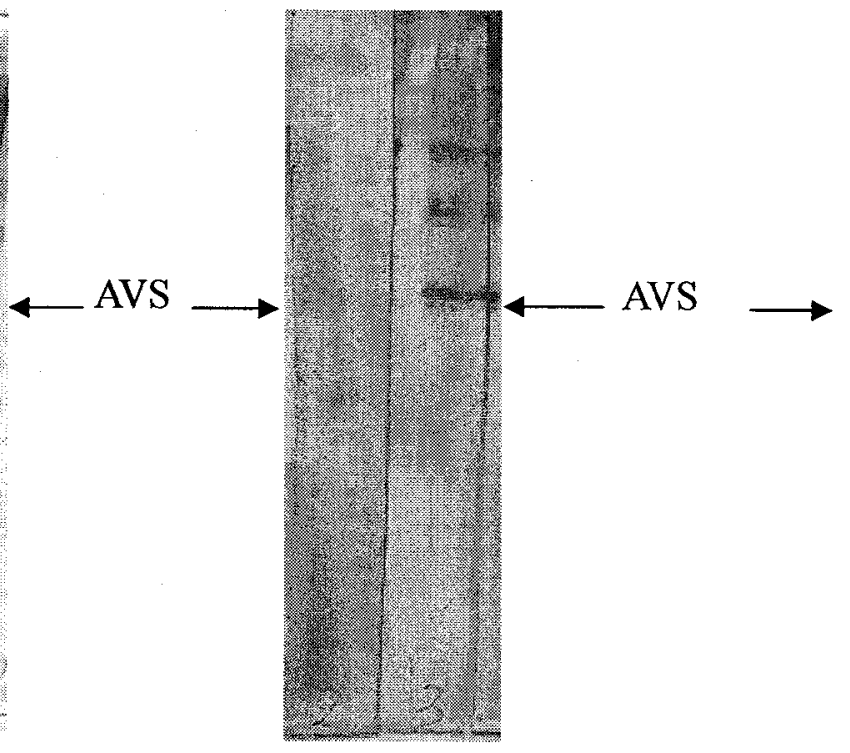

34

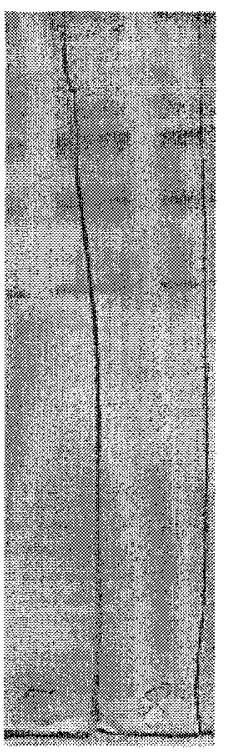

56 
Figure 6. Purification of AVL- PAb

1. AVL-PAb before protein $G$ purification

2. 1506 serum

3,4. AVL-PAb after protein $\mathrm{G}$ purification 


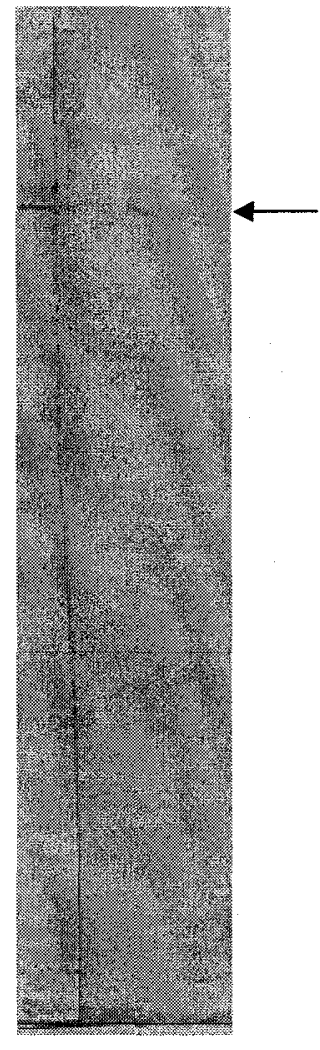

12

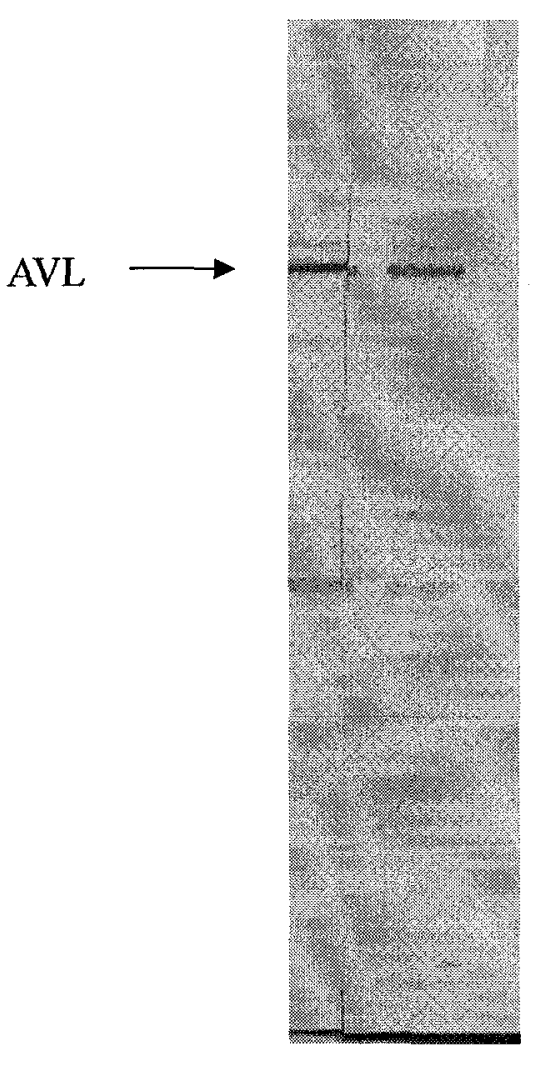

3

4 
Figure 7. Optimization of ammonium sulphate concentration for AVS separation

1. semi-pure AVS

2. $40-50 \%$ ammonium sulfate

3. $50-60 \%$ ammonium sulfate

4. $60-70 \%$ ammonium sulfate

5. $70-80 \%$ ammonium sulfate

*1506 serum used as the primary antibody. 


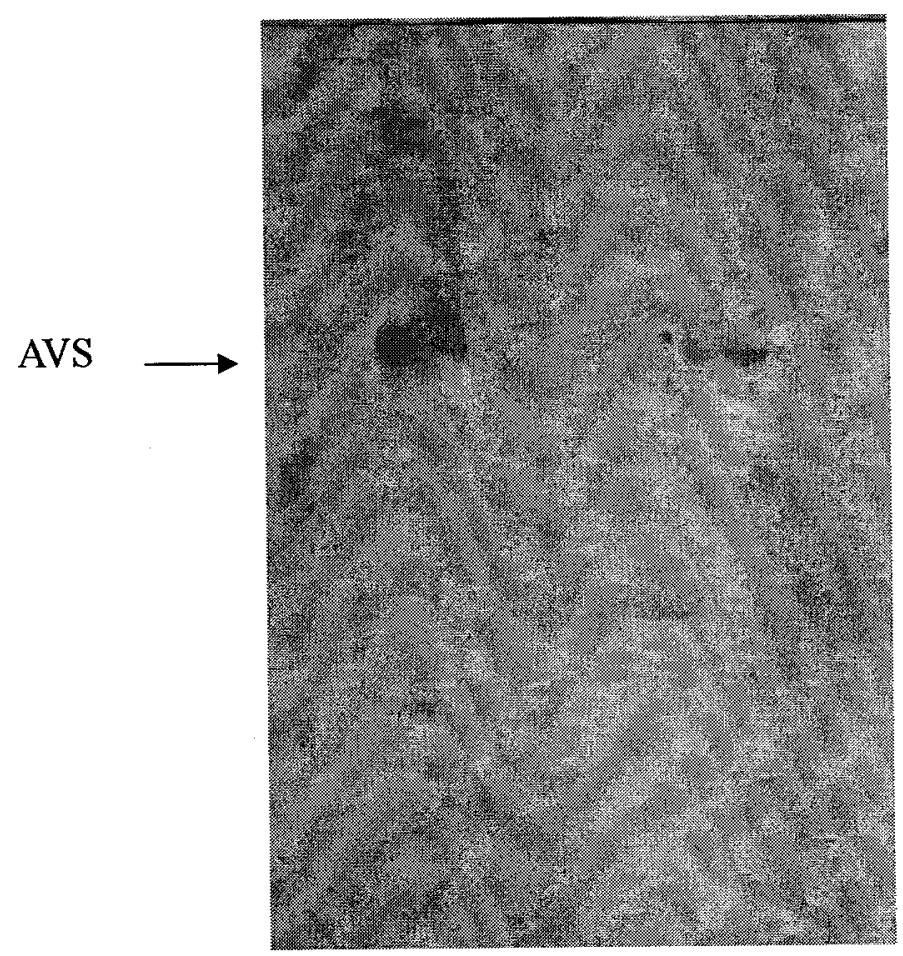

$\begin{array}{lllll}1 & 2 & 3 & 4 & 5\end{array}$ 
Figure 8. Optimization of ammonium sulfate concentration for AVL separation

1. semi-pure AVL

2. $40-50 \%$ ammonium sulfate

3. 50-60\% ammonium sulfate

4. $60-70 \%$ ammonium sulfate

5. $70-80 \%$ ammonium sulphate

*AVL-PAb used as the primary antibody 


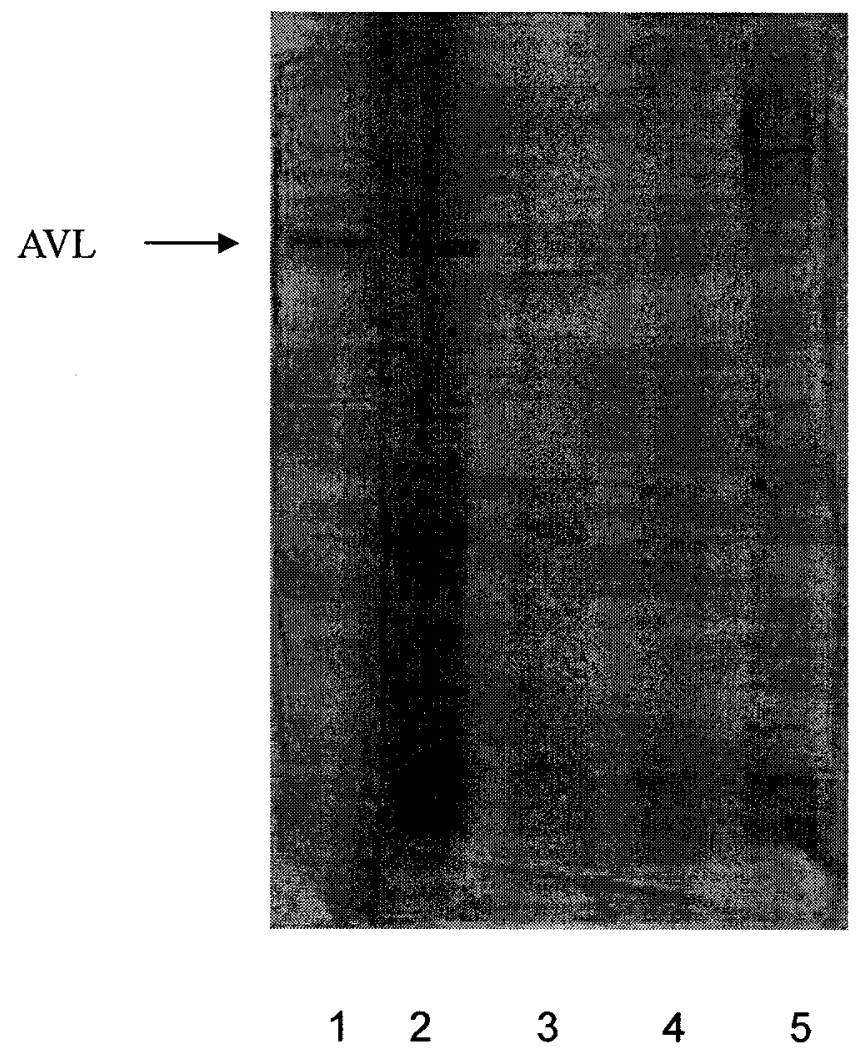


clear majority of AVS was recovered in the 60-70\% AS extract (Figure 7). In contrast, the intracellular fraction contained many proteins that showed some reaction with serum 1506. The majority of the AVL protein was contained in the $40-50 \%$ AS extraction, with some in the $50-60 \%$ extraction (Figure 8). For further purification steps, the two extracts were pooled.

Anion exchange chromatography was performed using the Q-Sepharose system. The results of experiments to determine the $\mathrm{NaCl}$ content required to remove the two target proteins from the ion exchange column are shown in two immunoblots (Figures 9 and 10). The effect of increasing the buffer $\mathrm{NaCl}$ concentration from $0.1 \mathrm{M}$ to $1.0 \mathrm{M}$ on the removal of the extracellular protein AVS from the column is shown on Fig. 9. The majority of AVS protein was removed at an $\mathrm{NaCl}$ concentration of $0.20 \mathrm{M}$. Similar experiments for the intracellular protein AVL indicated that the majority of this protein was removed at $0.15 \mathrm{M} \mathrm{NaCl}$ (Figure 10).

\subsubsection{Identification of antigenic proteins}

After purification with ion exchange, CBB stained gels and immunoblots were performed to visualize proteins and determined which protein produced activity toward the reactive human sera. A representative CBB-stained gel of the extracellular proteins from A.versicolor after ion exchange is shown in Figure 11. This demonstrated that the extracellular fraction that was isolated contained relatively few proteins in high concentration. Gels stained for protein, and visualized by antibodies from serum 1506 are shown in Figure 12. Two protein bands around $45 \mathrm{kDa}$ were visualized in the region of the target protein. To clarify which was the antigenic protein, the two bands were cut out 
Figure 9. Optimization of NaCL concentration to remove AVS from $\mathrm{Q}$ sepharose column

1. semi-pure AVS

2. AVS $50-60 \%$ ammonium sulfate fraction

3. wash

4. $0.10 \mathrm{M} \mathrm{NaCl}$

5. $0.15 \mathrm{M} \mathrm{NaCl}$

6. $0.20 \mathrm{MNaCl}$

7. $0.30 \mathrm{MNaCl}$ 


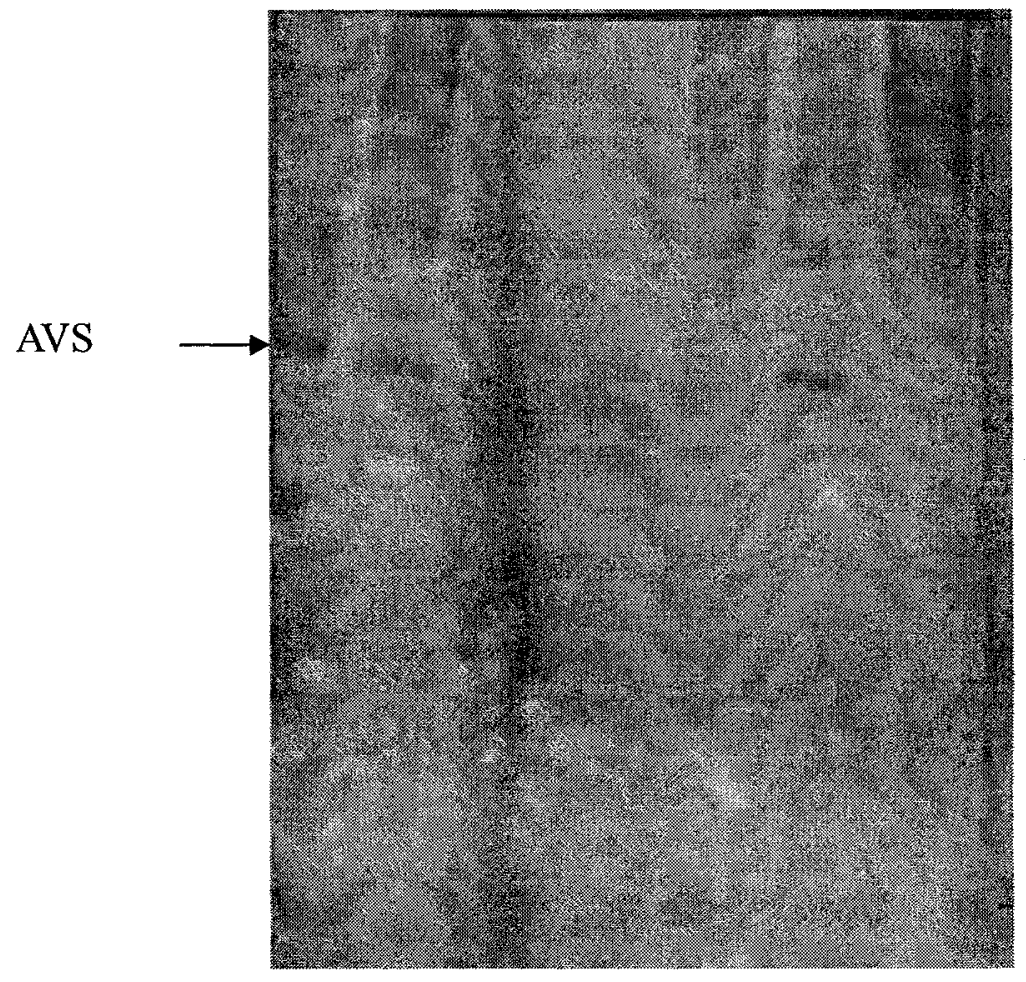

$\begin{array}{lllllll}1 & 2 & 3 & 4 & 5 & 6 & 7\end{array}$ 
Figure 10. Optimization of $\mathrm{NaCl}$ concentration to remove AVL from Q sephorose column

1. semi-pure AVL

2. AVL 40-60 ammonium sulfate fraction

3. wash

4. $0.05 \mathrm{M} \mathrm{NaCl}$

5. $0.1 \mathrm{M} \mathrm{NaCl}$

6. $0.15 \mathrm{M} \mathrm{NaCl}$

7. $0.20 \mathrm{M} \mathrm{NaCl}$

8. $0.30 \mathrm{M} \mathrm{NaCl}$

9. $1.0 \mathrm{M} \mathrm{NaCl}$

*AVL-PAb used as the primary antibody 


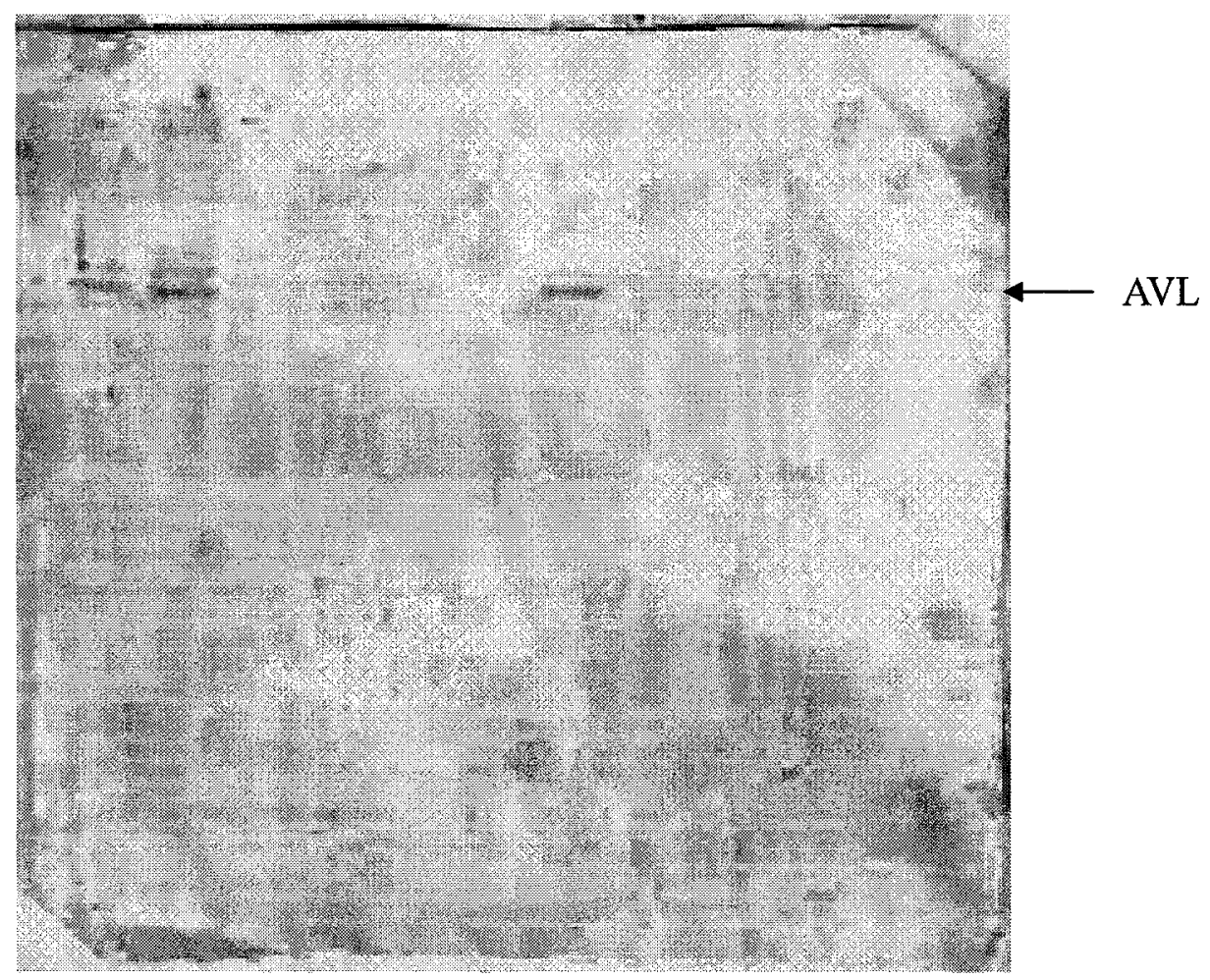
1
2
45
67
89 


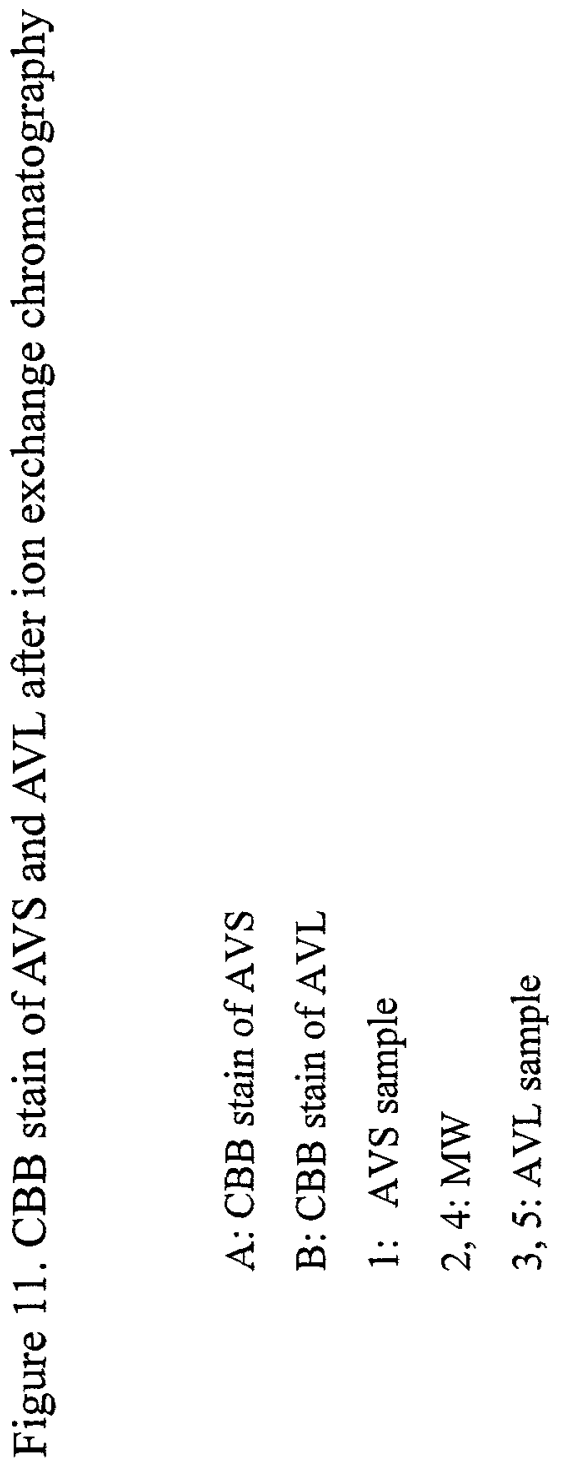




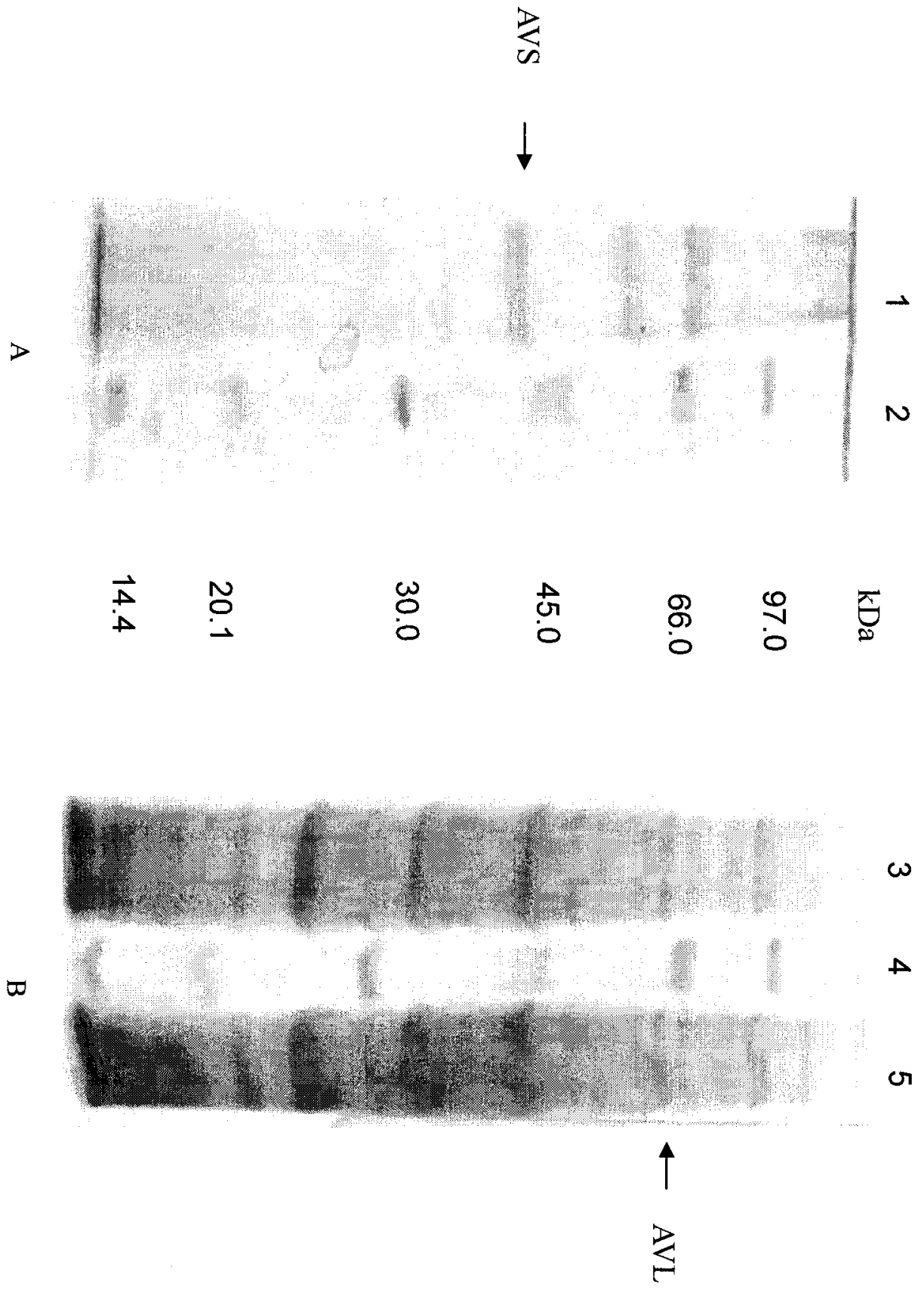


Figure 12. AVS after ion exchange chromatography comparing immunoblot and CBB stain gel

\author{
A: immunoblot using 1506 as the primary antibody \\ B: CBB stain of membrane of the same gel \\ C: SDS-PAGE gel stained with CBB \\ 1,2, 4 and 5: AVS (after ion exchange) \\ 3, $6: \mathrm{MW}$
}




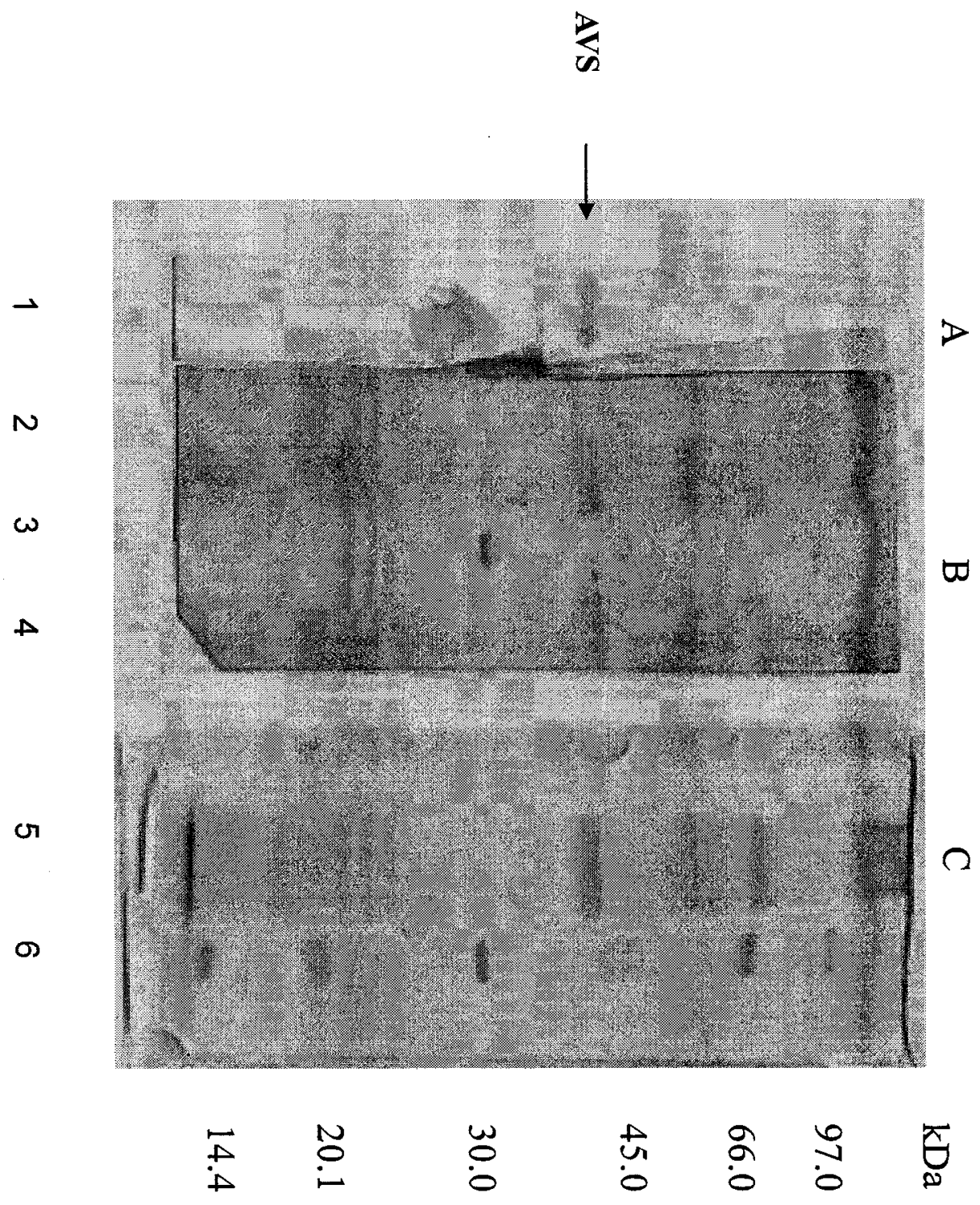


of the $\mathrm{CBB}$ stain gel and transferred to membrane separately to perform immunoblots. Before the transfer, the two protein bands were marked on the membrane using a needle to punch an indicator hole beside the band. The resulting immunoblot with patient serum is shown on Figure 13. The upper band (arrow) reacted to the antibody

The comparable data for the intracellular target protein is illustrated, again starting with material after the ion exchange column (Figure 11), with the following representative gels. The CBB-stained gel of the material taken through two purification steps (salt concentration, ion exchange column) shows many proteins (Figure 14). In a process similar to above, the protein bands were cut off from the CBB stained-gel and transferred to membranes for immunoblotting. The results of this are shown in Figure 15. Regardless of the large numbers of individual proteins in the intracellular fraction, on immunoblot, there was a strong band at ca. $65 \mathrm{kDa}$ and a less immunogenic protein at ca. $60 \mathrm{kDa}$.

\subsection{Further purification of AVS}

At this point, a decision was made that the more useful protein to focus on was AVS, thus the majority of the subsequent purification work reflects this choice.

Gel filtration was used to further purify AVS protein. Silver staining was performed to visualize the AVS protein band and Western blotting results determined the activity of the purified AVS-PAB as the primary antibody. The results of this purification are shown after silver staining and immunoblotting(Figures 16-17). AVS (arrow) can be seen in the gel stained with silver along with a 3-4 other proteins (Figure 16). Silver staining is sensitive to ca. 0.1 ng protein on a gel of this type; this indicated that the AVS preparation 


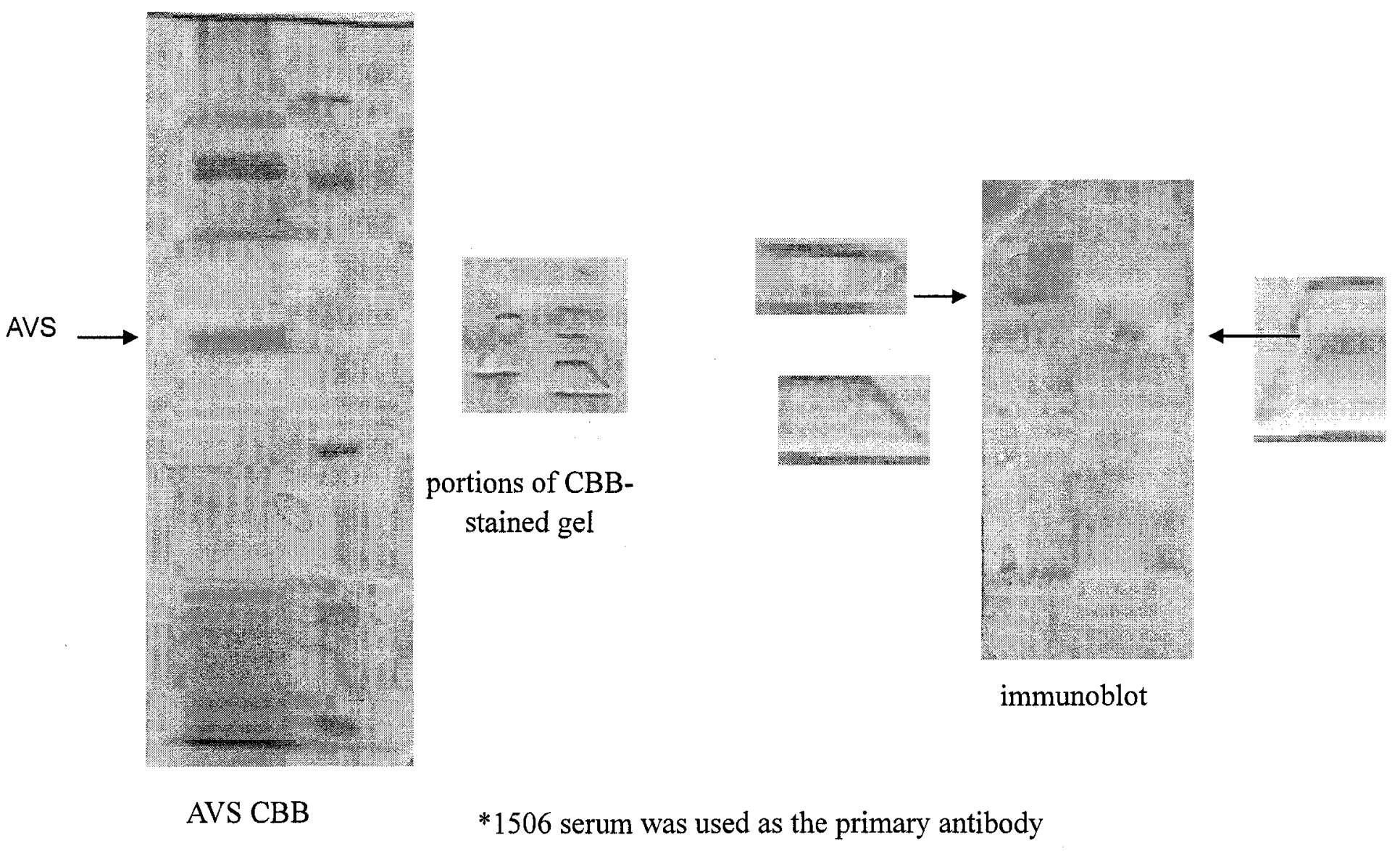

Figure 13 Identification of AVS by immunoblot* 
Figure 14. AVL after ion exchange chromatography: comparing immunoblot and CBB stained gel

\author{
A. immunoblot \\ B. CBB stained membrane of the same gel \\ C. SDS-PAGE gel stained with CBB \\ 1,2,4,5 \&7: AVL (after gel filtration) \\ $3 \& 6: M W$ \\ *1506 used as the primary antibody
}



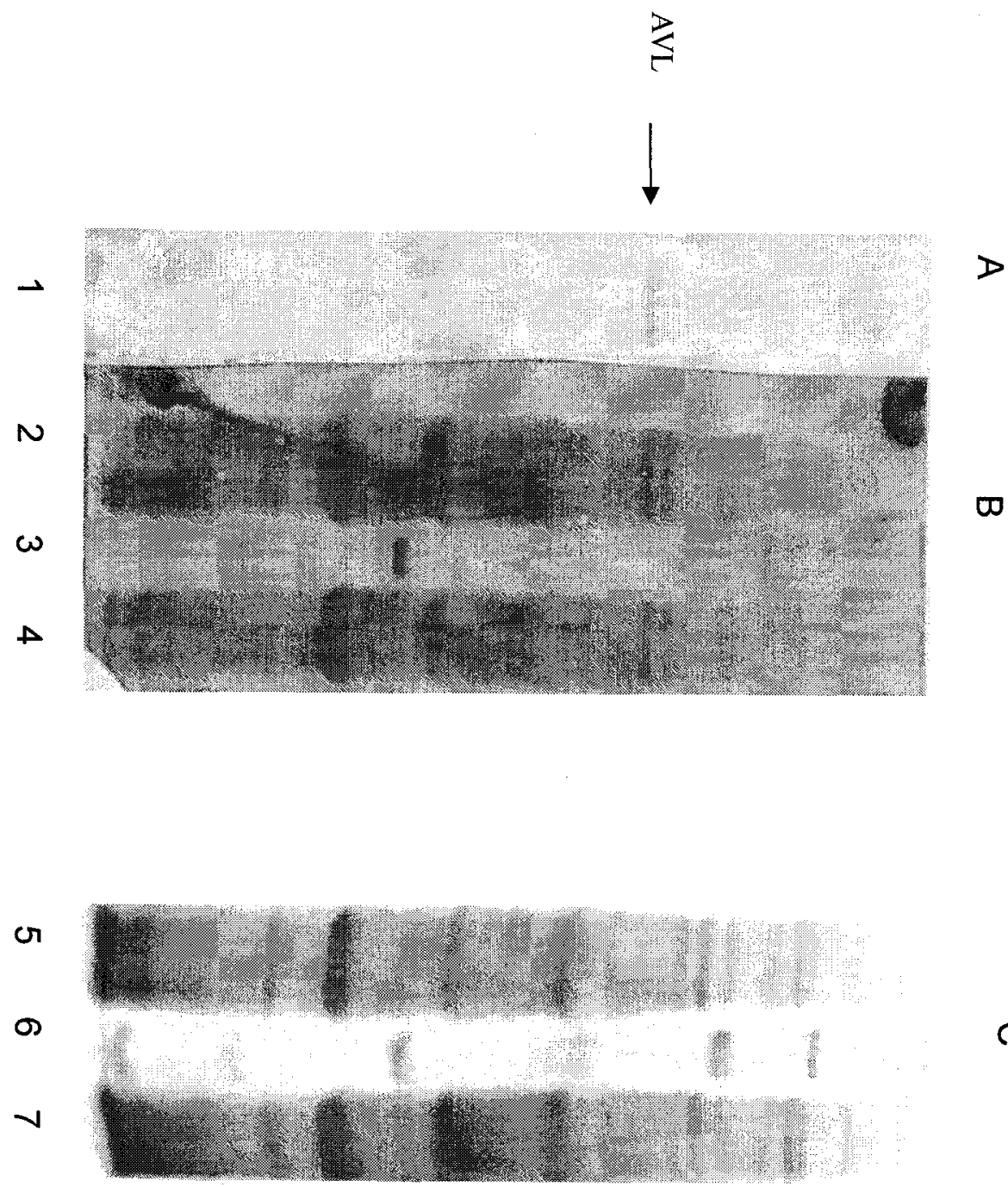

$\Omega$ 


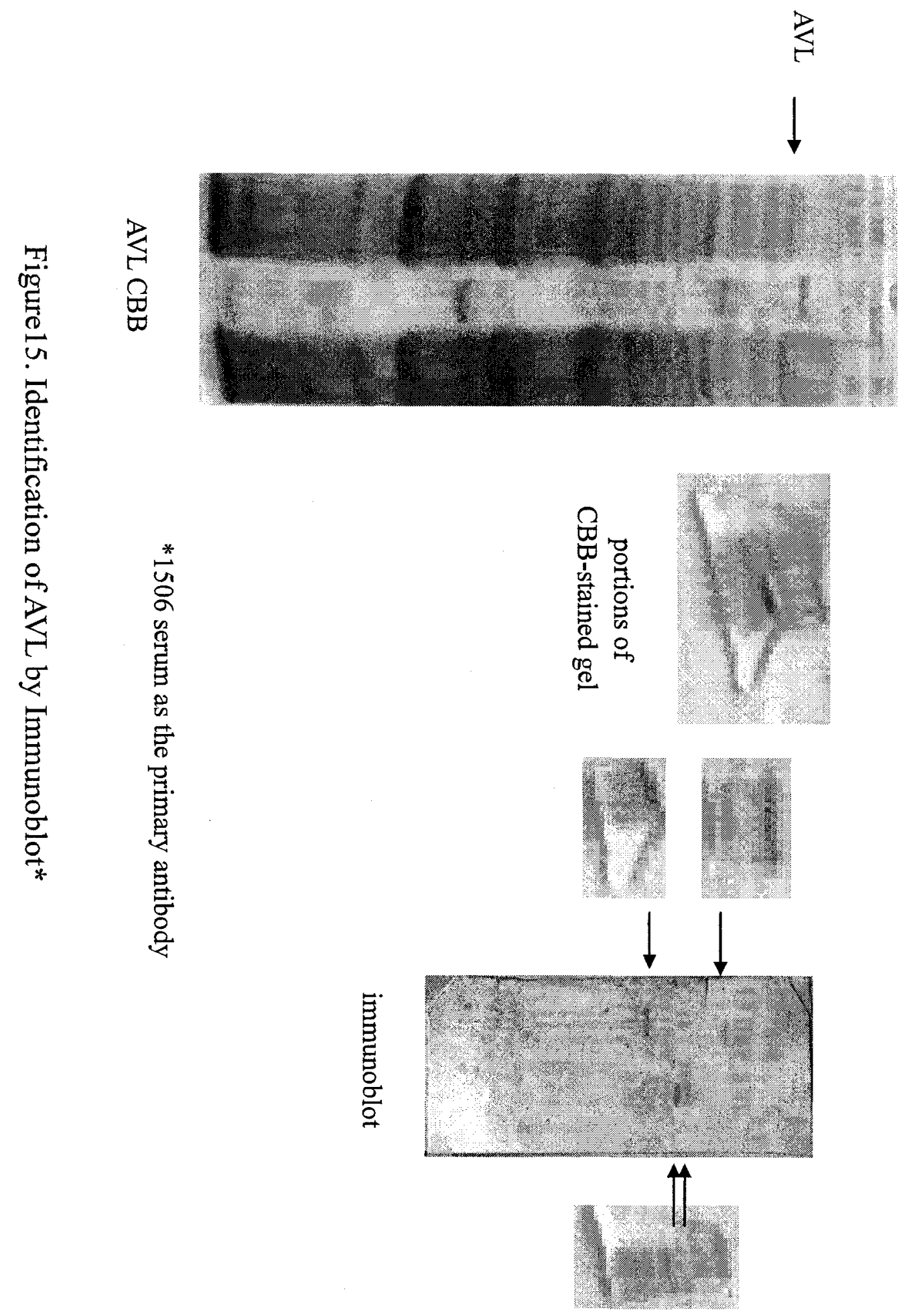


Figure 16. AVS preparation after gel filtration

1. $\mathrm{MW}$

2. AVS sample 


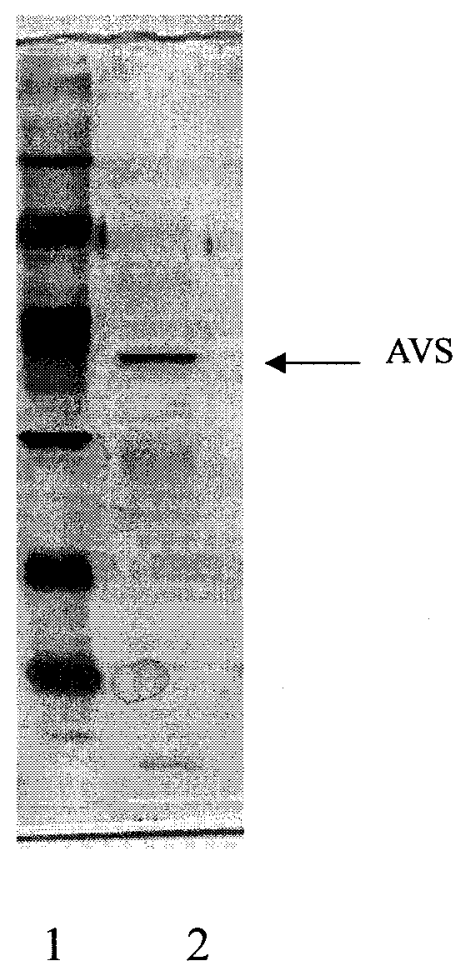


Figure 17. AVS preparation after gel filtration immunoblot

1. AVS sample(ion exchange)

2. AVS sample (gel filtration)

*AVS-PAb used as the primary antibody 


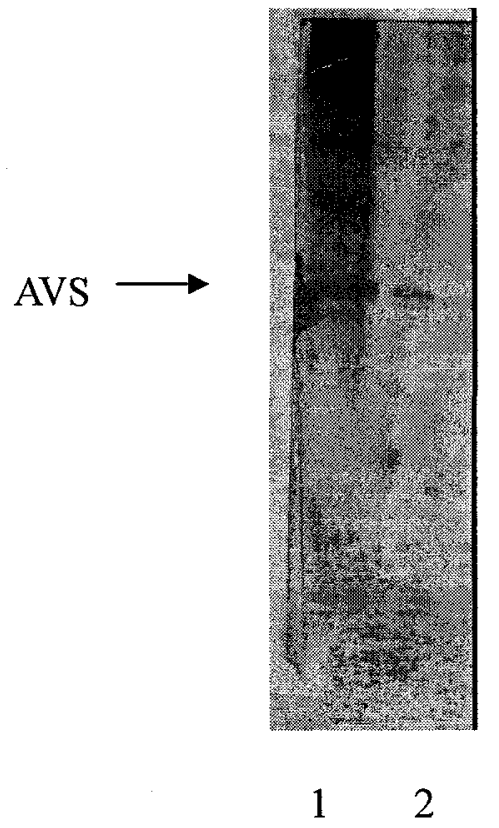


was $95-98 \%$ pure at this point. On immunoblotting, the majority of the response was to AVS (Figure 17).

A comparison of the material from various purification steps is shown on Figures 18, 19 and 20.

A CBB stained gel of the $60-70 \%$ ammonium sulfate fraction, the fraction off the ion exchange column, and that from the gel filtration column with 5 and 10 fold reductions in the amount of protein applied to the get at each step is shown on Figure 18. This shows the large number of proteins removed during the ion exchange chromatography compared to the AS fraction. Silver staining provides a more sensitive assay for protein. At the same protein amount applied to the gel through each step, the AVS from the ion exchange sample has by far the strongest band (Figure 19). Immunoblots of the same three preparations in immunoblot were visualized with serum 1506 and AVS-PAB on Figures 20 and 21, respectively. These demonstrate that the final preparation is antigenically pure based on the response to both of these PAbs.

Estimated levels of purification were achieved through the various steps are found in Table 2. This demonstrates a three fold gain in purity was achieved by ion exchange and an additional 6 fold purity increase after the gel filtration column purification.

Table 2. Recovery of the AVS protein through purification steps

\begin{tabular}{cccc}
\hline purification step & total protein $(\mathrm{mg})$ & AVS protein $(\mathrm{mg})$ & yield $(\%)$ \\
\hline 60-70 AS precipitation & $957.5 \pm 95.75$ & $4.79 \pm 0.48$ & $\approx 100$ \\
\hline Q-Sepharose & $3.15 \pm 0.32$ & $1.58 \pm 0.16$ & $\approx 33$ \\
\hline Gel filtration & $0.25 \pm 0.03$ & $0.25 \pm 0.03$ & $\approx 5.2$ \\
\hline
\end{tabular}


Figure 18. CBB stain of AVS with different amount of protein

1. $60-70 \%$ ammonium sulfate fraction, protein amount is $300 \mathrm{ug}$

2. ion exchange fraction, protein amount is $60 \mathrm{ug}$

3. gel filtration, protein amount is 6 ug

4. $\mathrm{MW}$ 


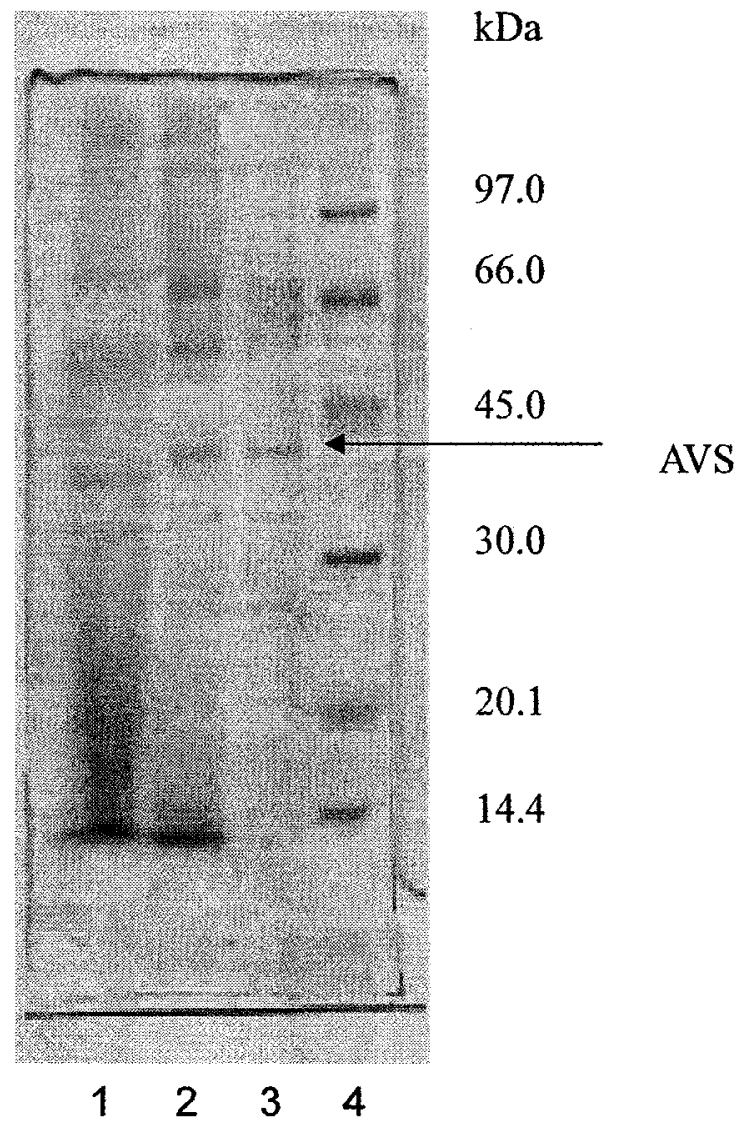


Figure 19. Silver stain of AVS with $3 \mu \mathrm{g}$ protein from each purification step

1. MW

2. $60-70 \%$ ammonium sulfate fraction

3. ion exchange fraction

4. gel filtration 


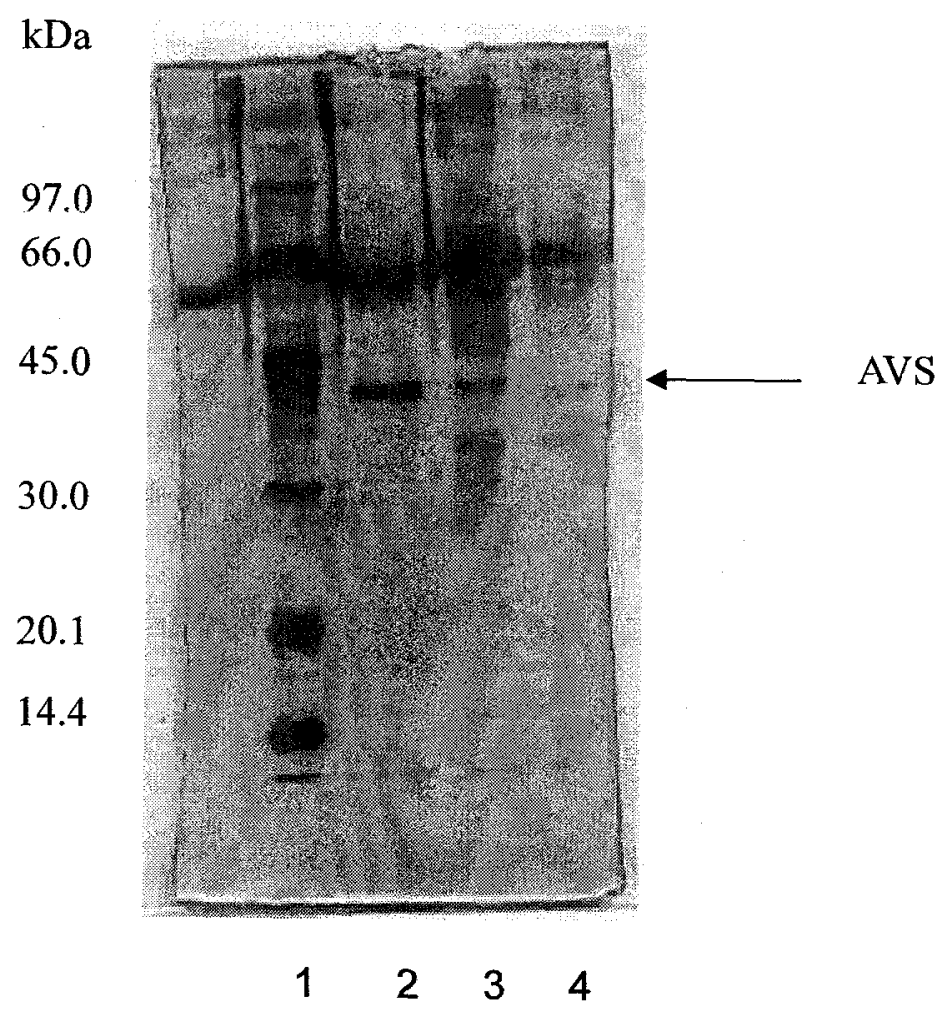


Figure 20. Immunoblot of AVS fraction from each purification step* ( $3 \mu \mathrm{g}$ of protein)

1. $60-70 \%$ ammonium sulfate fraction

2. ion exchange fraction

3. gel filtration

4. MW (Membrane stained with CBB)

*1506 serum used as the primary antibody 


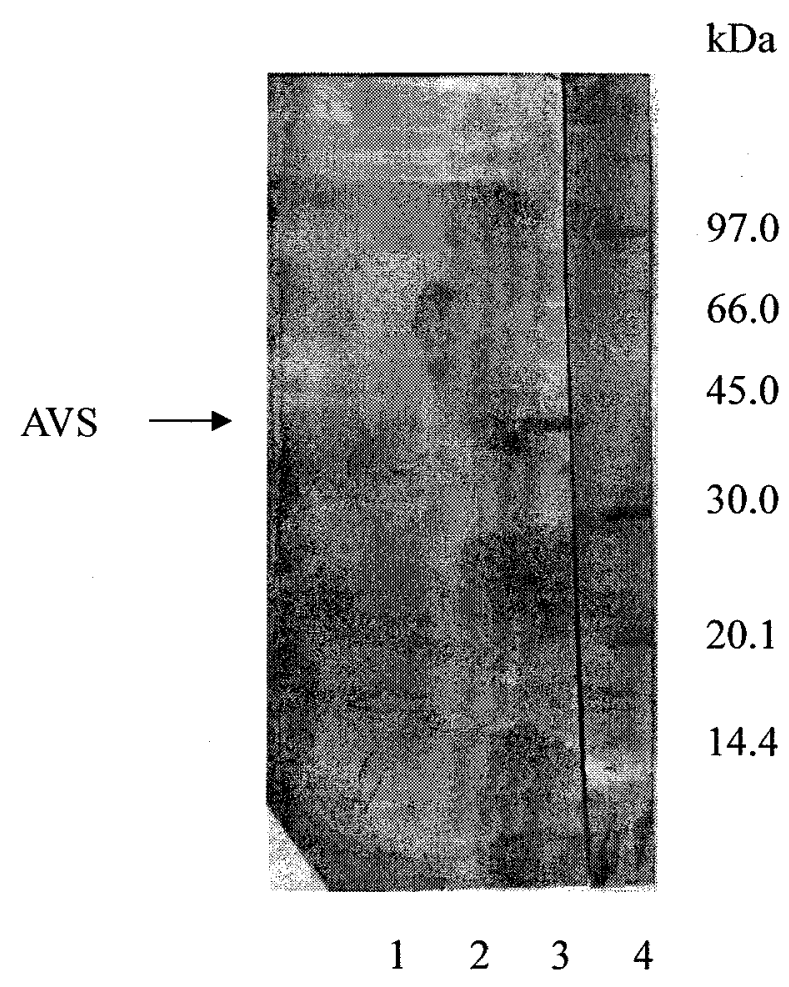


Figure 21. Immunoblot of AVS fractions from each purification steps* ( $3 \mu \mathrm{g}$ of protein)

1. $\mathrm{MW}$

2. $60-70 \%$ ammonium sulfate fraction

2. ion exchange fraction

4. gel filtration

*AVS-PAb used as the primary antibody 


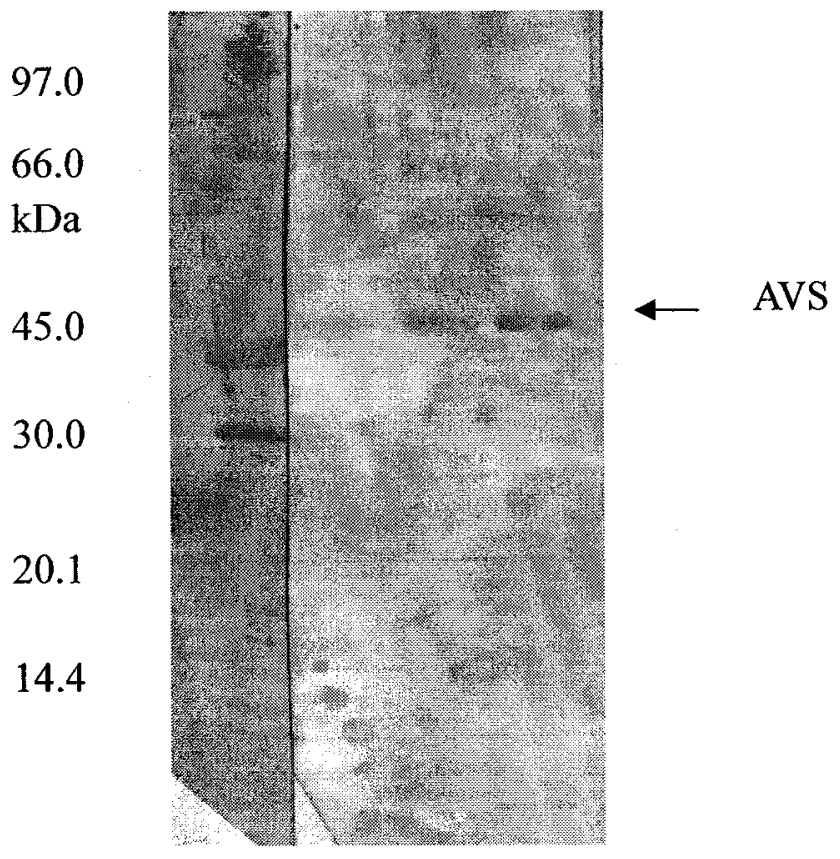

$\begin{array}{llll}1 & 2 & 3 & 4\end{array}$ 


\subsection{Molecular weight of AVS}

For determination of molecular weight by SDS, the molecular weights of the standards used ranged from $14-97 \mathrm{kDa}$. The standard curve prepared from these standards is shown in Figure 22. Based on this data, the best fit of $\log$ molecular weight versus $R_{f}$ was $y=-0.9983 \mathrm{X}+5.1033, \mathrm{r}^{2}=0.9889$. The equation was used to determine molecular weight, which were $47 \mathrm{kDa}$ for AVS and $61 \mathrm{kDa}$ and $65 \mathrm{kDa}$ for AVL.

The molecular weight of purified AVS was also verifiedby gel filtration using molecular weight standards from $12-2000 \mathrm{kDa}$. A representative chromatogram of one of the standards is shown in Figure 23. The standard curve prepared from the standards is shown on Figure 24. Based on these data, the log molecular weight versus elution volume resulted in a best fit curve described by $y=-0.0258 x+7.4818, r^{2}=0.9913$. A similar chromatogram of AVS is shown in Figure 25. This resulted in an estimated molecular weight for AVS of $45 \mathrm{kD}$. This is similar to the value obtained by SDS (47 kDa). That means that AVS is a monomeric protein.

\subsection{Cross-reactivity experiments using AVL-PAb and AVS-PAb}

Although antigen-antibody reactions are highly specific, it is possible for a particular antibody to react with an unrelated antigen due to a presence of a similar epitope. Two target proteins were identified in screening preliminary to this thesis as being potentially species diagnostic protein antigenic in humans and goats from $A$. versicolor. One, AVS was primarily, but not exclusively extracellular and the other, AVL, from the cell lysate. Optimization of the appropriate amount of primary antibody in the ELISA was based on purified AVS and AVL. 


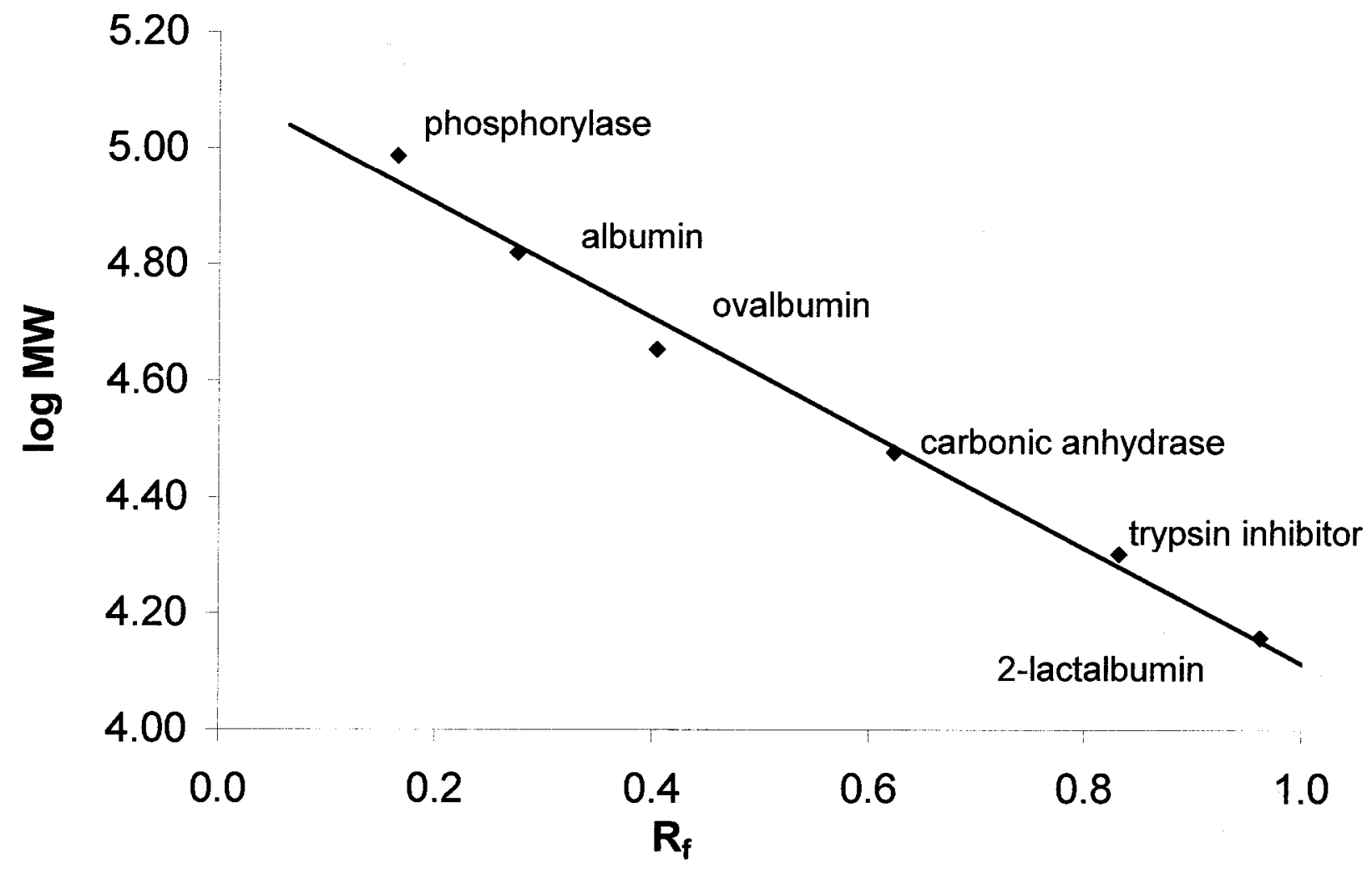

Figure 22. SDS-PAGE molecular weight standard curve 


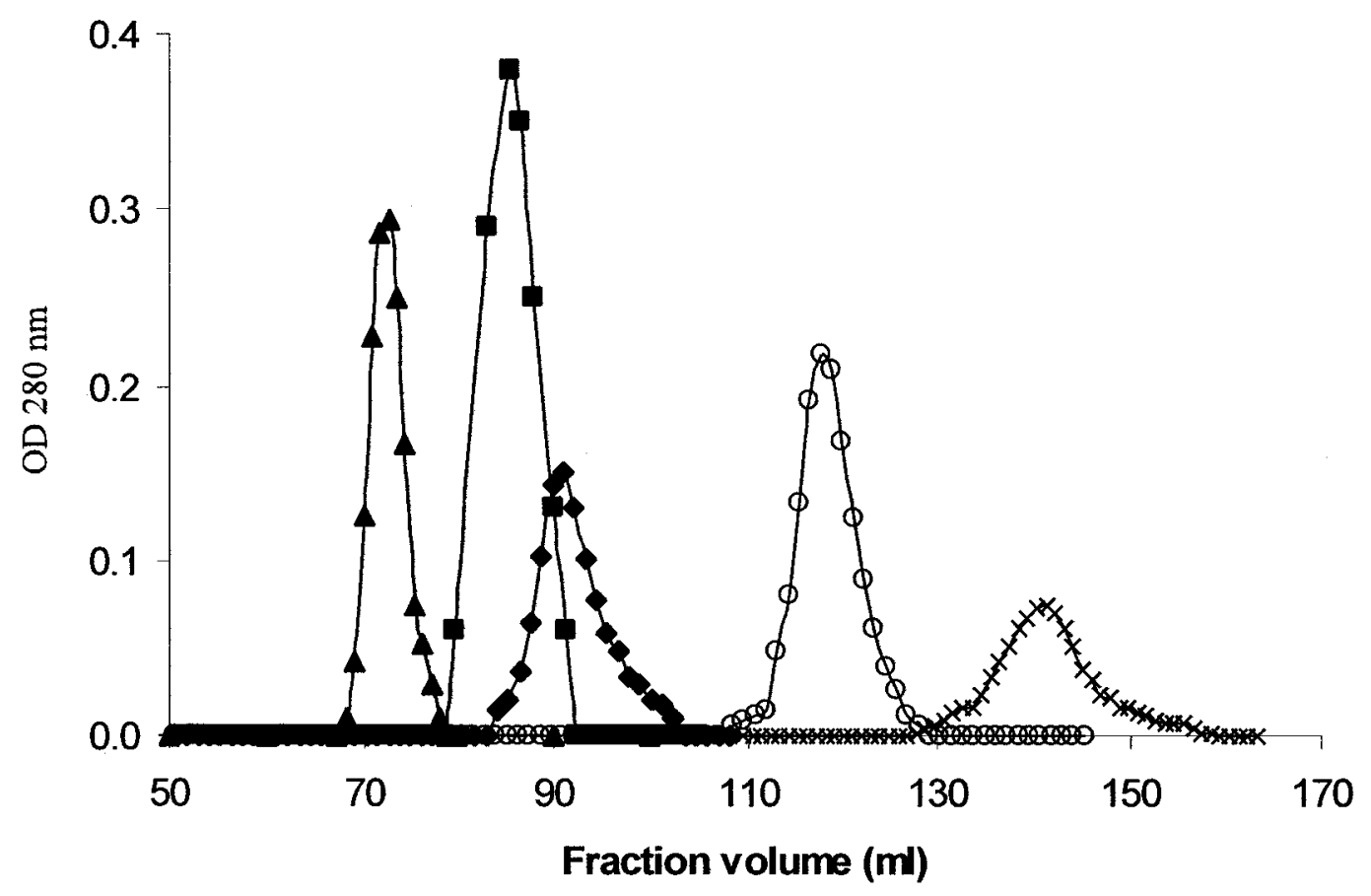

Figure 23. Chromatograph of gel filtration standards 


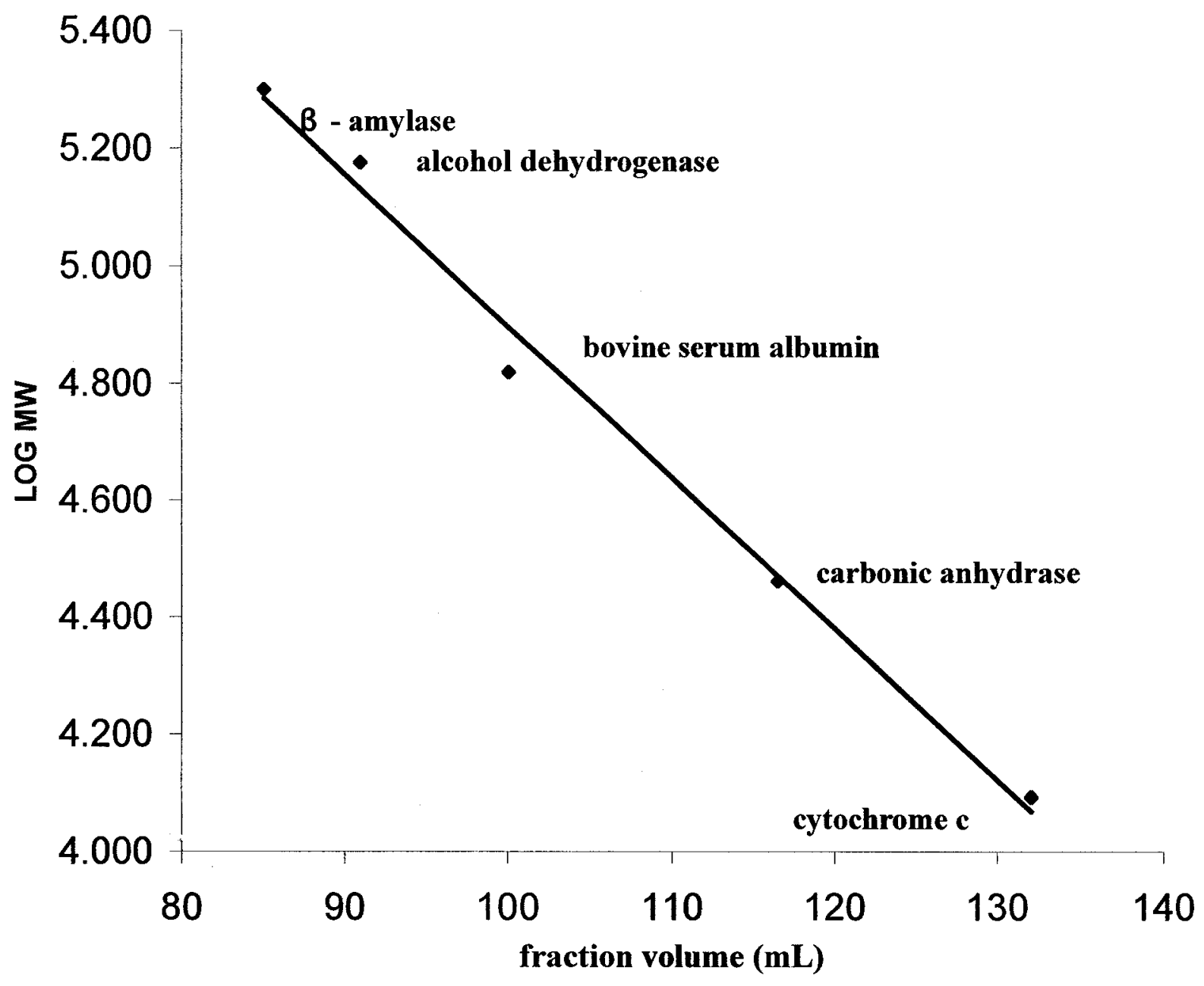

Figure 24. Standard curve for gel filtration Chromatography 


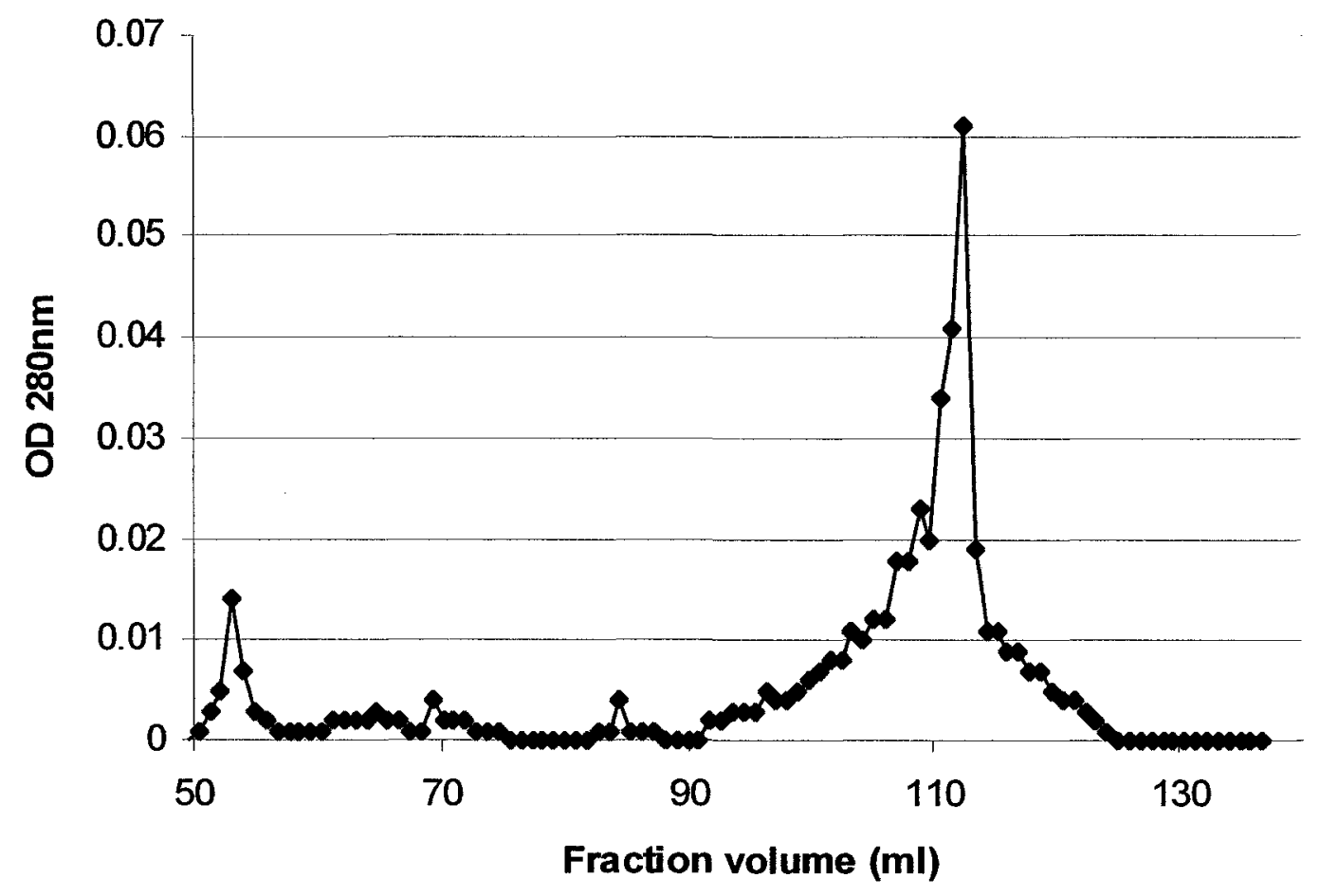

Figure 25. gel filtration chromatography of AVS 


\subsection{Purified AVS}

Standard curves derived by ELISA for $60-70 \%$ AS precipitation and material off the ion exchange column of the AVS protein through the first two purification steps. This was done to enable interpretation of the cross reactivity experiments. For the $60-70 \%$ ammonium sulphate preparation of a culture of $A$. versicolor DAOM 235361, the minimum amount of protein from which a response from AVS-PAB was obtained was ca. $1 \mu \mathrm{g} /$ well. The material after ion exchange had ca. 100 fold response by ELISA and the response was linear over a somewhat greater range. With the dilutions of primary and secondary antibodies used, the response was linear from 1 to $30 \mu \mathrm{g}$ protein/well.

\section{$\underline{3.7 \text { Spore extracts }}$}

PBS spore extracts from 14 species of fungi common on damp building materials including $A$. versicolor DAOM 235361 were examined for cross-reactivity using both AVS-PAB and AVL- PAB (Tables 3 and 4). This indicated that both polyclonal antibodies were relatively insensitive to the range of species tested. The cross reactivity of AVS-PAb with 4 different AVS spore strains, which from different sources, were also examined (Table 5). This indicated that AVS-PAb was common in strains collected from a wide area as noted in section 2.2 .

\subsection{Mycelial extracts}

Cell extracts were analyzed as described above the AVS-PAB and AVL-PAB, respectively. The amount of protein added was $20 \mu \mathrm{g} / \mathrm{well}$. This again indicated that both 
polyclonal antibodies were relatively insensitive to the range of species tested.

Table 3: The cross reactivity of AVL PAb with spores of different species in ELISA assay

\begin{tabular}{lcc}
\hline \multicolumn{1}{c}{ species } & OD $450 \mathrm{~nm}$ & $\begin{array}{c}\text { normalized to } \\
\text { protein content } \\
\text { of } \begin{array}{c}\text { A.versicolor } \\
\text { extract* }\end{array}\end{array}$ \\
\hline Aspergillus niger & 0.203 & 1.3 \\
A. flavus & 0.117 & 0.7 \\
A. fumigatus & 0.021 & 0.8 \\
A. ochraceus & 0.208 & 0.2 \\
A. ustus & 0.501 & 0.7 \\
A. versicolor 235361 & 1.887 & 1 \\
Eurotium amstelodomi & 0.000 & 0.5 \\
Paecilomyces varotii & 0.365 & 0.6 \\
Penicillum chrysogenum & 0.234 & 0.9 \\
P. expansum & 0.183 & 0.4 \\
Scorulopsis brevicaulis & 0.000 & 0.3 \\
Stachybotrys chartarum & 0.004 & 0.8 \\
S. chlorohalonata & 0.020 & 1.1 \\
Talaromyces. flavus & 0.601 & 0.7 \\
\hline
\end{tabular}

$* \times 10^{3}$ 
Table 4. The cross reactivity of AVS PAb with spores of different species on ELISA assay

\begin{tabular}{lcc}
\hline \multicolumn{1}{c}{ Species } & OD $450 \mathrm{~nm}$ & $\begin{array}{c}\text { normalized to } \\
\text { protein content of } \\
\text { A.versicolor } \\
\text { extract* }\end{array}$ \\
\hline Aspergillus niger & 0.186 & 1.3 \\
A. flavus & 0.167 & 0.7 \\
A. fumigatus & 0.181 & 0.8 \\
A. ochraceus & 0.203 & 0.2 \\
A. ustus & 0.272 & 0.7 \\
A. versicolor 235361 & 2.146 & 1 \\
Eurotium amstelodomi & 0.028 & 0.5 \\
Paecilomyces varotii & 0.165 & 0.6 \\
Penicillum chrysogenum & 0.516 & 0.9 \\
P. expansum & 0.263 & 0.4 \\
Scorulopsis brevicaulis & 0.262 & 0.3 \\
Stachybotrys chartarum & 0.028 & 0.8 \\
S. chlorohalonata & 0.143 & 1.1 \\
Talaromyces flavus & 0.574 & 0.7
\end{tabular}

$*_{\mathrm{X}} 10^{3}$ 
Table 5. The cross reactivity of AVS PAb with different of A.versicolor spore strains on ELISA assay

\begin{tabular}{|l|c|c|}
\hline \multicolumn{1}{|c|}{ spore strains } & source & OD 450nm \\
\hline Aspergillus versicolor DAOM 235361 & Winnipeg & 2.146 \\
\hline A.versicolor P5640-2 & Ottawa & 1.368 \\
\hline A.versicolor P6598-2 & Hawaii & 1.064 \\
\hline A.versicolor P5090-2 & California & 1.887 \\
\hline
\end{tabular}

DAOM: national mycological herbarium

P: Paracel Laboratory collection 


\section{Discussion}

Rydjord et al. (Rydjord et al., 2005) studied immunoglobulin G (IgG) antibodies against molds related to indoor dampness. They examined mold-specific IgG antibodies in sera from 106 Norwegian blood donors by ELISA for Penicillium chrysogenum,Cladosporium herbarum, Stachybotrys chartarum and Fusarium oxysporum. Their research suggested that the response to $A$. versicolor was stronger than to the other molds so another $\sim 1000$ blood donor sera were analyzed for IgG antibodies to this mould. In this Norwegian population, $12.5 \%$ were defined as positive to exposure. The research that led to this study performed similar screenings with sera from clinical tests selected for positive response by Pharmacia reagents to Stachybotrys, Aspergillus and Penicillium. From these sera, approximately one third responded by ELISA to extracts of 30 strains of $A$. versicolor selected at random from a wide geographic area. From the present work ( and that noted in section 2.2), two proteins appeared to be (1) common in all strains tested across a wide geographic area and (2) corresponding antibodies were present in all $A$. versicolor-positive serum samples.

It has long been known that the culture conditions have a large effect on the production of antibodies useful for recognizing fungal biomass in nature (e.g. Fallon \& Newell, 1989). Proteins that might be present in spores, spore fragments and mycelia in nature are not necessarily those first or easily accumulated in culture. The approach we used was produced a remarkably specific polyclonal antibody suitable for use as a capture antibody in a future assay. We attribute this remarkable specificity to three factors. First, inoculation of the goat with spore preparations that had not germinated stimulated only antibodies against proteins that occurred on spores (Figure 4). These might 
reasonably be assumed to be "natural". Second, the fermentations used to produce mycelium and culture filtrate gave reproducible results in the Western blots used to identify candidate antigens. The use of multiple human sera to identify antigens consistently produced by both different patients and different strains of the fungus narrowed the choice to antigens of greatest potential interest. Finally, the use of a strategy involving in effect expanding one or more of the most specific antibody lines induced by the spores improved the specificity of the polyclonal antibodies that resulted (Figure 4). This approach ensured three things: (a) the proteins involved were present in "natural" fungal cells, (b) they were associated with a human response and (c) the proteins isolated were present in the strains collected across the US and Canada.

In order to purify the initial target proteins, three purification steps were applied: (1) protein precipitation, (2) ion exchange column and (3) gel filtration. Proteins are usually soluble in water solutions because they have hydrophilic amino acids on their surfaces that attract water molecules and interact with them. This solubility is a function of the ionic strength and $\mathrm{pH}$ of the solution. Proteins have characteristic isoelectric points at which the charges of their amino acid side groups balance each other. If the ionic strength of a solution is either very high or very low proteins will tend to precipitate at their isoelectric point. The solubility is also a function of ionic strength. When the ionic strength was increased by adding salt, proteins will precipitate. AS is the most common salt used for this purpose because it is unusually soluble in cold buffers. AS fractionation is commonly used as a first step in protein purification because it provides some crude purification of proteins away from non-proteins and also separates some proteins. In this experiment, the AVS proteins were extracted by $60-70 \%$ ammonium sulfate, the AVL 
proteins were extracted by $40-50 \%$ AS solution (Figures 7 and 8 )

For the present experiments, ion exchange was the most useful protein purification and concentration method. Ion exchange purifies proteins based on differences between the overall charges of the proteins: negatively charged functional groups bind to cation exchangers, positively charged proteins bind to anion exchangers. Because this interaction is ionic, binding must take place under low ionic conditions. Elution is achieved by increasing the ionic strength to break up the ionic interaction. The proteins are composed of amino acids and amino acids have different overall charges at different $\mathrm{pH}$ values. Elution can therefore be achieved by changing the $\mathrm{pH}$ of the proteins. The AVL and AVS protein are negatively charged proteins when the $\mathrm{pH}$ is at 8.8 and 7.5 respectively. In this study, the anion exchange Q- Sepharose was used to purify the target proteins (Figures 9 and 10;12 and13). This increased the relative purity of the material by $>100$ times in the case of the target protein AVS (Table 5).

Proteins vary in molecular weight and hence size. Due to this fact, size can be used as a excellent method to separate them. Gel filtration is a type of size-exclusion chromatography. The "stationary phase" consists of beads with a well-defined range pore size. Small protein can fit inside all the pores in the beads and elute last in a gel filtration separation. Large proteins are two large to fit inside any of the pores and elute first. Intermediate-sized proteins can fit inside some but not all of the pores in the beads. Consequently, they elute between the large and small proteins. In this study, SephacryS200 was selected as gel filtration medium. This has $25-75 \mu \mathrm{m}$ pore size beads and can separate the protein size between 5 and $250 \mathrm{kDa}$ MW. This step provided improved the purity $\sim 2 \mathrm{x}$ over the previous material (Table 6 ). 
Table 6. Total a mount of isolated pure protein

\begin{tabular}{|l|c|c|c|c|}
\hline \multicolumn{1}{|c|}{ purification step } & $\begin{array}{c}\text { acetone } \\
\text { precipitation }\end{array}$ & $\begin{array}{c}60-70 \% \text { AS } \\
\text { precipitation }\end{array}$ & Q-Sepharose & sephacry \\
\hline volumn $(\mathrm{L})$ & 2.4 & 0.6 & $1.2 \times 10^{-2}$ & $1.2 \times 10^{-2}$ \\
\hline $\begin{array}{l}\text { Protein concentration } \\
(\mu \mathrm{g} / \mathrm{ml})\end{array}$ & $6.0 \times 10^{4}$ & $1.9 \times 10^{4}$ & $3.2 \times 10^{3}$ & $2.5 \times 10^{2}$ \\
\hline $\begin{array}{l}\text { amount of protein } \\
(\mathrm{mg})\end{array}$ & $1.4 \times 10^{5}$ & $1.1 \times 10^{4}$ & 38.4 & 3 \\
\hline AVS protein $(\mathrm{mg})$ & $*$ & 55 & 19.2 & 3 \\
\hline yield $(\%)$ & $*$ & 100 & 33 & 5.2 \\
\hline
\end{tabular}

SDS-PAGE is one of the most effective techniques for separating complex mixtures of proteins into their constituent polypeptides. SDS is an anionic detergent. When the molecules which have net negative charges within a wide $\mathrm{pH}$ range were dissolved in SDS, a polypeptide chain binds amounts of SDS in proportion to its relative molecular mass. The negative charges on SDS eliminates the tertiary and secondary structure of proteins, and are then strongly attracted toward an anode (positively-charged electrode) in an electric field proportionally to there molecular weight. In this study, the AVS molecular weight calculated by SDS-PAGE (i.e. the denatured protein) was $47 \mathrm{kDa}$ (Figure 22). To refine these estimates, gel filtration was used. Gel filtration proved to be a rapid, highly reproducible, and inexpensive method of determining molecular weights (Andrews 1962). The molecular weight of the AVS was estimated by gel filtration method at $45 \mathrm{kDa}$ (Figure 24). This molecular weight reflects the undenatured protein. This value is similar to that by SDS-PAGE $(47 \mathrm{kDa})$. This indicates that AVS is a monomeric protein. 
The IgG activities of the two $A$. versicolor target proteins: $60-70 \%$ ammonium sulphate precipitate and cell extract were compared using ELISA Assay. The standard curves showed that these two samples had similarly shaped activity-curves, but with different linear ranges. In the linear range, the absorbance increased very fast as the concentration increased. Ion exchange material was more responsive than the $60-70 \% \mathrm{AS}$ because of the greater purity.

Two antigens ( $45 \mathrm{kDa}$ and $65 \mathrm{kDa}$ ) have been purified from Aspergillus versicolor. The $45 \mathrm{kDa}$ proteins are extracellular in nature; the $65 \mathrm{kDa}$ protein is intracellular. At $\mathrm{pH}$ 7.5 , the $45 \mathrm{kDa}$ protein is negatively charged protein and at $\mathrm{pH} 8.865 \mathrm{kDa}$ protein is negatively charged. Atopic human 1506 was serum directed against both $45 \mathrm{kDa}$ and 65 $\mathrm{kDa}$ proteins. AVS-PAb reacted with $45 \mathrm{kDa}$ protein and AVL-PAb reacted with $65 \mathrm{kDa}$ protein. The evidence is that AVS is a monomeric protein.

Because of early results of the ELISA assays comparing the species specificity of AVS versus AVL (see below), a greater focus was placed on AVS in terms of purification effort. These purification steps provided very pure material of AVS used for the production of monoclonal antibodies (Table 6). Previous studies on fungal allergens have tended to focus in intracellular antigens because emphasis has been on harvesting and extracting large amounts of mycelium (Horner et al., 1995). The present study examined both culture filtrates and mycelium. A number of more recent studies at Carleton University (Xu et. al., 2006) have also shown the greater species specificity of extracellular proteins as well as for developing diagnostics for plant disease processes (Klosterman et al., 2001).

Relatively few clinically relevant allergens of fungi have been characterized (Horner 
et al., 1995). Despite the fact that allergens of Aspergillus species were among the first to be recognized as important aeroallergens, and some species cause aspergillosis, few specific allergens have been characterized from this genus.

As the number of identified allergens has increased, the number of different and often confusing terms for allergens increased. To resolve this problem, the International Union of Immunologic Societies Subcommittee for Allergen Nomenclature developed a nomenclature system for highly purified allergens and individual components detected within complex allergen extracts. Allergen identification is based on immunochemical and physicochemical techniques. Purified allergens are designated by the first three letters of the genus, the first letter of the species, and a numeral for their order of isolation. Roman numerals are reserved for gene designations, and Arabic numerals are used for protein designations (King, 1994). Fungal allergens are further labeled by the strain number. A summary of the currently recognized Aspergillus allergens is shown in Table 7.

Table 7. Purified Aspergillus allergens

\begin{tabular}{|c|c|c|c|c|}
\hline species & $\begin{array}{c}\text { allergen } \\
\text { name }\end{array}$ & $\begin{array}{l}\text { biochemical ID or } \\
\text { obsolete name }\end{array}$ & $\begin{array}{l}\text { MW (kDa) } \\
\text { SDS-PAGE }\end{array}$ & $\begin{array}{c}\mathrm{CP}^{*} \\
\text { sequence }\end{array}$ \\
\hline A. flavus & Asp fl 1 & $\begin{array}{c}\text { alkaline serine } \\
\text { protease }\end{array}$ & 34 & \\
\hline \multirow[t]{9}{*}{ A. fumigatus } & Asp f 1 & & 18 & C \\
\hline & Asp f 2 & & 37 & $\mathrm{C}$ \\
\hline & Asp f 3 & $\begin{array}{l}\text { peroxisomal } \\
\text { protein }\end{array}$ & 16 & $\mathrm{C}$ \\
\hline & Asp f 4 & & 30 & $\mathrm{C}$ \\
\hline & Asp f 5 & metalloprotease & 40 & \\
\hline & Asp f 6 & $\begin{array}{c}\text { Mn superoxide } \\
\text { dismutase }\end{array}$ & 26.5 & $\mathrm{C}$ \\
\hline & Asp f 7 & & 12 & $\mathrm{C}$ \\
\hline & Asp f 8 & $\begin{array}{l}\text { ribosomal protein } \\
\text { P2 }\end{array}$ & 11 & $\mathrm{C}$ \\
\hline & Asp f 9 & & 34 & $\mathrm{C}$ \\
\hline
\end{tabular}




\begin{tabular}{|c|c|c|c|c|}
\hline & Asp f 10 & Aspartic protease & 34 & $\mathrm{C}$ \\
\hline & Asp f 11 & $\begin{array}{c}\text { peptidyl-prolyl } \\
\text { isomeras }\end{array}$ & 24 & \\
\hline & Asp f 12 & $\begin{array}{l}\text { heat shock protein } \\
\text { P90 }\end{array}$ & 90 & $\mathrm{C}$ \\
\hline & Asp f 13 & $\begin{array}{c}\text { alkaline serine } \\
\text { protease }\end{array}$ & 34 & \\
\hline & Asp f 15 & & 16 & $\mathrm{C}$ \\
\hline & Asp f 16 & & 43 & $\mathrm{C}$ \\
\hline & Asp f 17 & & & $\mathrm{C}$ \\
\hline & Asp f 18 & $\begin{array}{c}\text { vacuolar serine } \\
\text { protease }\end{array}$ & 34 & \\
\hline & Asp f $22 w$ & enolase & 46 & $\mathrm{C}$ \\
\hline & Asp f 23 & $\begin{array}{l}\text { L } 3 \text { ribosomal } \\
\text { protein }\end{array}$ & 44 & $\mathrm{C}$ \\
\hline & Asp f 27 & cyclophilin & 18 & $\mathrm{C}$ \\
\hline & Asp f 28 & thioredoxin & 12 & $\mathrm{C}$ \\
\hline & Asp f 29 & thioredoxin & 12 & $\mathrm{C}$ \\
\hline \multirow[t]{4}{*}{$\begin{array}{c}\text { Aspergillus } \\
\text { niger }\end{array}$} & Asp n 14 & Beta-xylosidase & 105 & $\mathrm{C}$ \\
\hline & Asp n 18 & $\begin{array}{c}\text { vacuolar serine } \\
\text { protease }\end{array}$ & 34 & $\mathrm{C}$ \\
\hline & Asp n 25 & 3-phytase B & $86-100$ & $\mathrm{C}$ \\
\hline & Asp n & & 85 & $\mathrm{C}$ \\
\hline \multirow[t]{2}{*}{$\begin{array}{c}\text { Aspergillus } \\
\text { oryzae }\end{array}$} & Asp o 13 & $\begin{array}{c}\text { alkaline serine } \\
\text { protease }\end{array}$ & 34 & $\mathrm{C}$ \\
\hline & Asp o 21 & amylase $\mathrm{A}$ & 54 & $\mathrm{C}$ \\
\hline
\end{tabular}

*C: cDNA, P: peptide

Adapted from international Union of Immunological Societies Allergen Nomenclature SubCommittee

There are only four of aspergillus species in the currently accepted list: two pathogens (A. fumigatus, A. flavus) and two fungi used in industrial fermentations $(A$. niger, $A$ oryzae).

One important A. flavus allergen (Asp fl 1) was identified by means of immunoblotting with a serum pool of allergic patients on a two-dimensional electrophoretic gel (Chia-Jung et al., 1999). The cDNA coding for Asp fl 1 was cloned 
and sequenced. The clone encoded a protein of 403 amino acids of $42 \mathrm{kDa}$. After cleavage of a putative signal peptide of 21 amino acids and a peptide of 100 amino acids, a mature protein of 282 amino acids was obtained with a molecular mass of $33 \mathrm{kDa}$ and a pI of 6.3. This protein was relatvitly similar to bacterial subtilisin, Pen c 1 , and a virulence factor of A. fumigatus. Recombinant Asp fl 1 (rAsp fl 1) was cloned into vector pQE-30 and expressed in E. coli M15 as a histidine-tag fusion protein and purified to homogeneity. The IgE binding capacity of rAsp fl 1 was tested by immunoblotting using a serum pool of Aspergillus-allergic patients. This recombinant allergen cross-reacted strongly with IgE specific for natural Asp fl 1 and Pen c 1 (Chia-Jung et al., 1999).

Several antigens have been purified from A. fumigatus by chromatography (Samuelsen et. al., 1991). The $18 \mathrm{kDa}$ (Asp f 1) antigen was isolated from the mycelium of 10 different strains of the fungus. The amino acid sequence of the $18 \mathrm{kDa}$ protein (Asp f 1) has been partially determined (Arruda et al., 1992; Arruda et. al., 1990). Asp f 1 shows sequence homology (95\%) to mitogillin (a cytotoxin) produced by $A$. restrictus(Arruda et.al., 1992). A cross-inhibition radioimmunoassay with a murine Mab and human IgG and IgE antibodies revealed that Asp $f \quad 1$ and mitogillin are indistinguishable antigenically.

Other $A$. fumigatus allergens include a peroxisomal protein, a manganese-dependent superoxide dismutase and a number of unknown proteins, some of which are diagnostic for allergic reactions to the fungus and others that are not (Kurup et.al, 2001). The recombinant antigen, Asp f 16, a $43 \mathrm{kDa}$ protein, was evaluated with ELISA and immunoblots using sera from patients and normal subjects (Banerjee et. al., 2001). Seventy percent of the patients with ABPA demonstrated high level of serum IgG 
antibodies to Asp f 16, whereas patients with allergic asthma, Aspergillus skin testpositive asthmatics without clinical evidence of $\mathrm{ABPA}$, and normal control failed to show Asp f 16-specific IgE binding by ELISA. The deduced amino acid sequence of Asp f 16 showed extensive sequence homology to $30.6-\mathrm{kDa}$ Asp $\mathrm{f} 9$ at the $\mathrm{N}$-terminal region of the protein. PBMC from the majority of patients with ABPA exhibited significant with the recombinant Asp f 16 allergen.

Several enzymes from $A$. niger and $A$. oryzae are used as conditioners or enhancers in bakery products. Some of these enzymes are identified as causing IgE-mediated sensitization in up to $25 \%$ of bakers with workplace-related symptoms (Sander et. al., 1998). Allergenic activity among baking and food industry workers has been demonstrated for a cellulase, xylanase and glucoamylases from $A$. niger and $A$. oryzae (Horner et. al., 1995). Twenty-three percent of 171 tested bakers had specific IgE to alpha-amylase, $8 \%$ reacted to glucoamylase, $13 \%$ reacted to cellulase, and $11 \%$ reacted to xylanase. Xylanase and cellulase preparations, each containing at least 6 different proteins, showed cross-reactivity in the range of $80 \%$. The main IgE-binding protein in the xylanase preparation recognized in 7 of 8 xylanase-positive subjects was a protein of about $105 \mathrm{kD}$. This protein was identified as $\beta$ - xylosidase by peptide mass spectrometric fingerprinting. The identification was confirmed by matching 12 peptide sequences obtained by $\mathrm{N}$-terminal and mass spectrometric sequencing to this protein (Sander et al., 1998).

Of the $\sim 30$ currently accepted major and minor allergens from Aspergillus species, the proteins include alkaline serine proteases, a peroxisomal protein, a metalloprotease, Mn-superoxide dismutase, ribosomal protein P2, aspartic protease, peptidyl-prolyl 
isomerase, heat shock protein P90, enolase, L 3 ribosomal protein, cyclophilin, thioredoxin, beta-xylosidase, 3-phytase B, amylase $\mathrm{A}$ as well as a variety of other related uncharacterized proteins including various cellulases and other degradative enzymes. Only two of these come close in molecular weight to the AVS protein we have found in $A$. versicolor, an enolase and L3 ribosomal protein from A. fumigatus, both of which are minor allergens. In contrast, AVS is a major antigen from A. versicolor.

The AVS-PAb and AVL-PAb were tested for cross-reactivity against 16 fungal species (Table 8 and 9). Some of the species tested were other environmental Aspergillus species, the other 7 of them are unrelated species. As expected, $A$ versicolor had by far the highest sensitivity for both AVS-PAb and AVL-PAb. Aspergillus niger, A. flavus, A. fumigatus and A. ustus showed minor reactivity with AVS-PAb and AVL-Pab. None of the unrelated fungi showed material cross-reactivity from mycelia extracts. Testing with this mixture of nominally related and unrelated fungi (e.g. Stachybotrys) suggests that AVL and AVS are not found in other taxa. This is remarkable because the literature indicates that Aspergillus and Penicillium share multiple antigens (Horner et al. 1995). 
Table 8. The cross reactivity of AVS-PAb with some mycelia extracts by ELISA Assay

\begin{tabular}{ll}
\hline \multicolumn{1}{c}{ fungus } & OD 450nm \\
\hline Alternaria alternata & 0.142 \\
Aspergillus.niger & 0.624 \\
A. penicilloides & 0.284 \\
A. fumigatus & 0.246 \\
A. versicolor & 1.851 \\
Chaetomium globosum & 0.199 \\
Cladosporium cladosporioides & 0.360 \\
Epicoccum nigrum & 0.029 \\
Memnoniella echinata & 0.031 \\
Penicillum commune & 0.527 \\
P. chrysogeum & 0.471 \\
P. corylophulem & 0.055 \\
P. spinulosm & 0.100 \\
Scorulopsis brevicaulis & 0.028 \\
S. echinata & 0.094 \\
Wallemia sebi & 0.111 \\
\hline
\end{tabular}

Extract of $20 \mu \mathrm{g}$ mycelia 
Table 9. The cross reactivity of AVL-PAb with some mycelia extracts by ELISA Assay

\begin{tabular}{ll}
\hline \multicolumn{1}{c}{ fungus } & OD $450 \mathrm{~nm}$ \\
\hline Alternaria alternata & 0.550 \\
Aspergillus.niger & 0.529 \\
A. penicilloides & 0.338 \\
A. fumigatus & 0.300 \\
A. versicolor & 1.190 \\
Chaetomium globosum & 0.233 \\
Cladosporium cladosporioides & 0.234 \\
Epicoccu nigrum & 0.290 \\
Memnoniella echinata & 0.115 \\
Penicillum commune & 0.687 \\
P. corylophulem & 0.314 \\
P. chrysogeum & 0.454 \\
Stachybotrys echinata & 0.566 \\
\hline Eallemia sebi & 0.427 \\
\hline
\end{tabular}

extract of $20 \mu \mathrm{g}$ mycelium

The results from the milled spores were similar i.e. there was no evidence that AVS or AVL were present in either notionally related or unrelated taxa (Tables 3 and 4). Spore protein contents were found to be quite variable roughly as a function of spore size as has been seen for ergosterol (Miller \& Young, 1997). A.ochraceus had the lowest per spore protein concentration (calculated from Table 1). S. chlorohalonata had the fewest spores 
protein concentration (calculated from Table 1). S. chlorohalonata had the fewest spores but had the highest protein concentration.

The other remarkable thing that emerged from testing both mycelia extracts and spores was that the content of AVS was very much higher in spores versus mycelium $(>10,000 \mathrm{x})$. In the former, on the order of $\mathrm{ng}$ protein were added per well and for the mycelium, the protein content was $20 \mu \mathrm{g} /$ well. To my knowledge, this has not been reported from previous research of this type.

There is currently only one study on antibody production for detection $A$. versicolor based on unknown proteins (a very different research strategy than used here). Schmechel et al. (Schmechel et al., 2006) produced MAbs by immunizing the mice with the particulates from homogenized spores. The MAbs were tested for cross-reactivity against 55 fungi (not deposited in culture collections). None of the MAbs was found to be species-specific. Several MAbs strongly cross-reacted with most Aspergillus, Penicillium and Eurotium species and some MAbs also cross-reacted with Paecilomyces varioii and several Cladosporium and Stachybotrys species. In contrast, both AVS-PAb and AVL-PAb are high species-specific PAbs against $A$.versicolor. 


\section{References:}

Andrews, P. (1962) Estimation of molecular weights of proteins by gel filtration. Nature, 196: $36-9$.

Arruda, L.K., Mann, B.J., and Chapman, M.D. (1992) Selective expression of a major allergen and cytotoxin, Asp f 1, in Aspergillus fumigatus. J. Immunol., 149: 3354-3359

Arruda, L.K., Platts-Mills, T.A.E., Fox, J.W., and Chapman, M. D. (1990) Aspergillus fumigatus allergen I, a major IgE-binding protein, is a member of the mitogillin family of cytotoxins. J. Exp. Med., 172: 1529-1532

Banerjee, B., Kurup, V.P., Greenberger, P.A., Johnson, B.D. and Fink, J.N. (2001)

Cloning and expression of Aspergillus fumigatus allergen Asp f 16 mediating both humoral and cell-mediated immunity in allergic bronchopulmonary aspergillosis (ABPA). Clin. Exp. Allergy, 31: 761-770

Barnes, S.E., Dola, T. P., Bennet, J. W. t, and Bhatnagar, D. (1994) Synthesis of sterigmatocystin on a chemically defined medium by species of Aspergillus and Chaetomium. Mycopathologia, 125: 173-178.

Block, S.S. (1953) Humidity requirements for mold growth. Appl. Microbiol.,1: 287-293. Bush, R.K., and Yunginger, J.W. (1987) Standardization of fungal allergens. Clin. Rev. Allergy, 5: 3-21. 
Chang, J.C.S., Foarde, KK. and Van Osdell, D.W. (1996) Assessment of fungal (Penicillium chrysogenum) growth on three HVAC duct materials. Enviro. Int., 22: 425431

Chapman, M. D. (1989) Monoclonal antibodies as structural probes for mite, cat and cockroach allergens. In A. E. Shami and T. G. Merrett (ed.), Advances in Biosciences, vol. 74. Allergy and molecular biology. Pergamon Press, Inc., Elmsford, N.Y. p281-295

Chia-Jung Y., Shyh-Horng C., Wei-Yu L., Bor-Luen C. and Lu-Ping C. (1999) Characterization of a novel allergen, a major IgE-binding protein from Aspergillus flavus, as an alkaline serine protease. Biochem. Biophys. Res. Commun., 261: 669-675

Cruz, A., Saenz de S. and Pagen, J. (1995) Are fungal spores the main sensitizing components in mold allergy? Allergy, 50: 346

Dales RE., Zwanenburg, H., Burnett, R. and Franklin, C.A. (1991) Respiratory health effects of home dampness and molds among children. Am. J. Epidemiol, 134: 196-293.

Day, J.H. and Ellis, A.K. (2000) Allergenic microorganisms and hypersensitivity. In: Flannigan, B., Samson, R. and Miller, J.D. Microorganisms and indoor work environments. Taylor \& Francis, London. p. 101-128, 
DeShazo R.D. and Swain, R.E. (1995) Diagnostic criteria for allergic fungal sinusitis. J. Allergy Clin. Immunol., 96: 24-35.

Dreborg, S., Agrell, B., Foucard, T. , Kjellman, N. I. M., Koivikko, A., and Nilsson. S. (1986) A double-blind, multicenter immunotherapy trial in children, using a purified and standardized Cladosporium herbarum preparation. Allergy, 41: 131-140.

Esch, R.E. (2004) Manufacturing and standardizing fungal allergen products J Allergy Clin. Immol., 113: 210-215

Fogelmark, B., Sjostrand, M. and Rylander, R. (1994) Pulmonary inflammation induced by repeated inhalation of Beta (1,3)-D-glucan and endotoxin. Int. J. Exp. Pathol., 75: 8590.

Foto, M., Vrijmoed, L.L.P, Mille,r J.D., Ruest, K., Lawton, M., Dales, R.E. (2005) Comparison of airborne ergosterol, glucan and Air-O-Cell data in relation to physical assessments of mold damage and some other parameters. Indoor Air 15: 256-266.

Flannigan, B. and Miller, J.D. (2001) Microbial growth in indoor environments. In: Flannigan, B., Samson, R.A.and Miller J.D. (eds) Microorganisms in home and indoor work environments: Taylor \& Francis, London. p35-67

Harber, P., Schenker, MB. and Balmes, JR. (1996) Occupational and Environmental 
Respiratory Diseases. Mosby, St. Louis

Helm, R.M., Squillace D. L. and Yunginger J. W. (1988) Production of a proposed international reference standard Alternaria extract. II. Results of a collaborative trial. Int. Arch. Allergy Appl. Immunol., 81: 651-663.

Horak, B., Dutkiewicz, J. and Solarz, Z. (1996) Microflora and acarofauna of bed dust from homes in Upper Silesia, Poland. Annals of Allergy, Asthma, and Immunology 76(1): 41-50.

Horner W.E (2005) The damp building effect: understanding needed, not more debate. Annals of Allergy, Asthma \& Immunol, 94: 213-215.

Horner, W. E., Helbling, A., Salvaggio, J.E. and Lehrer, S.B. (1995) Fungal Allergens. Clin. Micro. Rev. p 161-179

Hobart M.J. (1975) Immune system. Oxford, Blackwell Scientific, London.

Iversen, M., Pedersen, B. (1990) The prevalence of allergy in Danish farmers. Allergy, 45: $347-353$

Juha, J., Hannu, K., Veli-Matti K., Aino, N, Jukka, P., Maija-Riitta H. (2002) Spores of Aspergillus versicolor isolation from indoor air of a moisture-damaged building provoke 
acute inflammation in mouse Inha. Toxicol., 14:1261-1277

Kendric, B. (2001) Fifth Kingdom, Third Edition. Mycologue Publications, Sidney, BC

Klosterman, S.J., Chen, J.J., Hoi, J.J., Chinn, E.E. and Hadwiger, LA. (2001) Characterization of a $20 \mathrm{kDa}$ DNase from Fusarium solani f. sp. phaseoli and its expression at the onset of induced resistance in Pisum sativum. Mol. Plant Pathol., 2:147158.

King, T.P., Hoffman, D. and Thomas, W. (1994) Allergen nomenclature. Allergy Clin. Immunol. News, 6: 38-44

Kurup, V. P., Xia, J.-Q., Crameri, R., Rickaby, D. A., Choi, H. Y., ckiger, S. F., Blaser, K., Dawson, C. A. and Kelly, K. J. (2001) Purified Recombinant A. fumigatus Allergens Induce Different Responses in Mice. Clin. Immunol., 98: 327-336

Laemmli U.K.(1970) Cleavage of structural proteins during the assembly of the head of bacteriophage T4. Nature, 227(5259): 680-685

Latge, J.P., Moutaouakil M., Debeaupuis, J.P., et al. (1991) The 18 kilodalton antigen secreted by Aspergillus fumigatus. Infec.Immun., 59: 2586-2594.

Lehrer, S. B., and Salvaggio. J. E. (1990). Allergens: standardization and impact of biotechnology-a review. Allergy Proc., 11: 197-208. 
Li, C.S. and Hsu, L.Y. (1997) Airborn fungus allergen in association with residential characteristics in atopic and control children in a subtropical region. Archives Enviro. Heal.,52: 72-79

Lowry, O.H., Rosebrough, A.L., Farr, A.L. and Randall, R. J. (1951) Protein measurement with Folin-phenol reagent. Biol. Chem. 193: 265-275

Miller, JD. (1992) Fungi as contaminants in indoor air. atomospheric Environ., 26: 21632172

Nielsen, K. F., Gravesen, S., Nielsen, P. A., Andersen, B., Thrane, U., and Frisvad, J.C. (1999) Production of mycotoxins on artificially and naturally infested building materials. Mycopathologia, 145: 43-56

National Academy of Science (2000) Clearing the air: asthma and indoor air exposures. NAS Press, Washington.

Platts-Mills, T. A. E. (1985) Problems in allergen standardization. Clin. Rev. Allergy, 3: $271-290$.

Salvaggio, J. E., Burge, H. A. and Chapman, J. A. (1993) Emerging concepts in mold allergy: what is the role of immunotherapy? J. Allergy Clin. Immunol., 92: 217-222. 
Samson, R. A, Flannigan, B., Flannigan, M. E., Verhoeff, A. P., Adan, O. C. C., and Hoekstra, E. S. (1994). Health implications of fungi in indoor environments Elsevier, Amsterdam.

Samuelsen, H., Karlsson-Borga, A., Paulsen, B. S., World, J. K. and Rolfsen, W. (1991) Purification of a $20 \mathrm{kDa}$ allergen from Aspergillus fumigatus. Allergy, 46: 115-124

Sander, I., Raulf-Heimsoth, M. and Siethoff, C. (1998) Allergy to Aspergillus-derived enzymes in the baking industry: Identification of $\beta$-xylosidase from Aspergillus niger as a new allergen (Asp n 14). Occup. Health ND. Med., 39 (5): 230-238.

Schmechel, D., Simpson, JP. and Lewis, DM. (2005) The production and characterization of monoclonal antibodies to fungus Aspergillus versicolor. Indoor Air, 15: 11-19.

Soto-Quiros, M., Gutierrez, I., Calvo, N., Araya, C., Karlberg, J., Hanson, LA., and Belin, L. (1998) Allergen sensitization of asthmatic and nonasthmatic school children in Costa Rica. Allergy, 53: 1141-1147

Sorenson, W.G. (1999) Fungal spores: Hazardous to health? Environ.Health perspect., 107: $469-472$.

Strachan, N.D. (1998) Damp housing and childhood asthma: validation of reporting of 
symptoms. British Med. J., 297(6658): 1223-1226.

Su H.J., Rotnitzky, A., Burge, HA., and Spengler, JD. (1992) Examination of fungi in domestic interiors by using factor analysis: correlations and associations with home factors. Appl. Environ. Microbiol. 58: 181-186

Traber, R., Hofmann, H. and Kobel, H. (1989) Cyclosporins--new analogues by precursor directed biosynthesis. J Antibiot (Tokyo), 42:591-597.

Tuomi, T. K., Reijula, T., Johnsson, K., Hemminki, E. L., Hintikka, O., Lindroos, S., Kalso, P., Koukila-Kähkölä, H., Mussalo-Rauhamaa and Haahtela, T. (2000). Mycotoxins in crude building materials from water-damaged buildings. Appl. Environ. Microbiol., 66: 1899-1904

Womiloju, T.O., Miller, J.D., Mayer, P.M., Brook, J.R. (2003) Methods to determine the biological composition of particulate matter collected from outdoor air. Atmospheric Environment 37:4335-4344

Turkeltaub, P. C., Rastogi, S. C., Baer, H., Anderson, M. C. and Norman, P. S. (1982). A standardized quantitative skin-test assay of allergen potency and stability: studies on the allergen dose-response curve and effect of wheal, erythema, and patient selection on assay results. J. Allergy Clin.Immunol. 70: 343-352. 
Williamson IJ., Martin CJ., McGill, G., Monie, RD. and Fennerty, AG.. (1997). Damp housing and asthma: a case-control study. Thorax, 52: 229-234.

Xu, J., Belilise, D. and Miller, J.D. (2006) Purification and characterization of a protein from Stachybotrys chartarum antigenic in humans. Med. Mycol., (In press) 